\title{
1 Is galactose a hormetic sugar? Evidence from rat hippocampal redox regulatory network
}

3 Homolak $\mathrm{J}^{1,2}$, Babic Perhoc $\mathrm{A}^{1,2}$, Knezovic $\mathrm{A}^{1,2}$, Kodvanj $\mathrm{I}^{1,2}$, Virag $\mathrm{D}^{1,2}$, Osmanovic Barilar $\mathrm{J}^{1,2}$, Riederer $\mathrm{P}^{3,4}$, Salkovic-

4 Petrisic $\mathrm{M}^{1,2}$

$5 \quad{ }^{1}$ Department of Pharmacology, University of Zagreb School of Medicine, Zagreb, Croatia

$6 \quad{ }^{2}$ Croatian Institute for Brain Research, University of Zagreb School of Medicine, Zagreb, Croatia

$7 \quad \quad{ }^{3}$ Clinic and Polyclinic for Psychiatry, Psychosomatics and Psychotherapy, University Hospital Wuerzburg,

8 Wuerzburg, Germany

$9 \quad{ }^{4}$ University of Southern Denmark Odense, Odense, Denmark
11

12

13

14

15

16

17

18

+385919411468 
bioRxiv preprint doi: https:/doi.org/10.1101/2021.03 08.434370; this version posted March 8,2021 . The copyright holder for this preprint (which was not certified by peer review) is the author/funder, who has granted bioRxiv a license to display the preprint in perpetuity. It is made available under aCC-BY-NC-ND 4.0 International license.

\section{Abstract}

Galactose is a ubiquitous simple monosaccharide with yet incompletely understood biochemical and physiological role. Most of what we currently know about galactose is based on induction from the research on inherited disorders of galactose metabolism and animal models that exploit galactose-induced oxidative stress to model aging in rodents, however, recent evidence also demonstrates unique properties of galactose to conserve cellular function during the periods of starvation, and prevent and alleviate cognitive deficits in a rat model of sporadic Alzheimer's disease. Here, we try to understand the molecular background of both detrimental and beneficial effects of galactose by exploring the acute systemic and hippocampal biochemical changes upon oral administration of galactose solution focusing primarily on the components of the redox regulatory network (RRN). Although orogastric gavage of galactose solution (200 mg/kg) was insufficient to induce systemic RRN disbalance in the first two hours upon administration, analysis of hippocampal RRN revealed a mild pro-oxidative shift accompanied by a paradoxical increase in tissue reductive capacity, suggesting overcompensation of endogenous antioxidant systems in the response to the pro-oxidative stimulus. The more thorough analysis revealed that galactose-induced increment of reductive capacity was accompanied by inflation of the hippocampal pool of nicotinamide adenine dinucleotide phosphates indicating ROS detoxification through disinhibition of the oxidative pentose phosphate pathway flux, reduced neuronal activity, and upregulation of Leloir pathway gatekeeper enzyme galactokinase-1. Based on the observed findings, and in the context of previous work on galactose, we propose a hormetic hypothesis of galactose action suggesting that the protective effects of galactose might be inseparable from its pro-oxidative effects at the biochemical level.

Keywords: galactose; hormesis; oxidative stress; pentose phosphate pathway; reductive capacity; antioxidant 
bioRxiv preprint doi: https:/doi.org/10.1101/2021.03.08.434370; this version posted March 8, 2021. The copyright holder for this preprint (which was not certified by peer review) is the author/funder, who has granted bioRxiv a license to display the preprint in perpetuity. It is made available under aCC-BY-NC-ND 4.0 International license.

\section{Introduction}

Galactose is a simple monosaccharide that was first discovered by Pasteur in $1856^{1}$. In structural terms, galactose differs from glucose, the most important energy substrate, only in the configuration of the hydroxyl group attached to the $\mathrm{C} 4$ carbon $^{2}$. However, a plethora of evidence suggests that this modest structural difference enabled galactose to be selected by evolution to play an important biological role in a wide variety of living organisms. The importance of galactose is best illustrated in the following findings. Galactose, both in its free monosaccharide form, and attached to other molecules forming oligosaccharides, polysaccharides, glycoproteins, or glycolipids, has been identified in many living organisms including bacteria, plants, and animals ${ }^{2}$. Furthermore, the milk sugar lactose, known to be an essential nutrient for the development of nurslings, consists of galactose and glucose, and in rare lactose-free mammalian milk, found only in sea lions and marsupials, galactose is still present, usually in a trisaccharide form to provide energy and structural support for the developing brain ${ }^{3}$. Although the exact explanation why galactose has been selected by evolution as a component of lactose remains one of the biggest and most puzzling questions in biology ${ }^{4}$, its unique biochemical role offers some hints. Recent advancements in the field of glycobiology offer plenty of evidence that glycosylation serves a critical role in neural development, differentiation, axonal pathfinding, and synapses, explaining why a correct glycosylation pattern is a requirement for a functional nervous system ${ }^{5,6}$. Galactose can be utilized in glycosylation through multiple biochemical pathways ${ }^{7}$ and unlike glucose or mannose, the presence of galactose enables cells to maintain mature glycosylation patterns during times of sugar starvation ${ }^{4}$. In this context, current evidence suggests that the importance of galactose for living organisms might be related to its unique metabolic fate enabling galactose to ensure constant availability of glycosylation substrates. At the biochemical level, such an effect could be exerted by escaping strong regulatory mechanisms that are diverting metabolism exclusively towards energy generating systems during times of deficient nutrient availability. Interestingly, more than 160 years after its discovery, the physiological significance of galactose remains largely unknown, with the largest fraction of the accumulated scientific knowledge on galactose provided from two main sources: studies focused on galactosemia, a group of inherited disorders characterized by a reduced capacity of enzymes involved in galactose metabolism, and animal experiments focused on aging in which chronic parenteral administration of galactose to healthy animals is used to model oxidative stress-related pathophysiological mechanisms driving senescence. Both, however, offer limited understanding of the physiological significance of galactose pathways 
bioRxiv preprint doi: https:/doi.org/10.1101/2021.03.08.434370; this version posted March 8, 2021. The copyright holder for this preprint (which was not certified by peer review) is the author/funder, who has granted bioRxiv a license to display the preprint in perpetuity. It is made available under aCC-BY-NC-ND 4.0 International license.

and whether they can be used to supply additional energy ${ }^{8}$, restore glycosylation patterns ${ }^{4}$, reduce ammonia load and promote cerebral amino acid synthesis ${ }^{9}$ without inducing oxidative stress with well known detrimental consequences $^{10}$.

Galactosemia is sometimes referred to as proof of detrimental effects of galactose, however, a substantial body of evidence accumulated over the last few decades clearly shows that pathophysiological repercussions are a result of biochemical rerouting rather than the accumulation of the galactose substrate per $s e^{11}$. This is further corroborated by the fact that regardless of the specific enzyme deficiency, galactose accumulation occurs in all subtypes of galactosemia, but clinical manifestations differ greatly ${ }^{11}$. For example, galactokinase (GALK; EC 2.7.1.6) deficiency (Type II Galactosemia; MIM 230200) has been associated with a mild clinical presentation with cataracts often being the only evident abnormality ${ }^{12}$. In contrast, mutations in galactose-1-phosphate uridylyltransferase (GALT; EC 2.7.7.12) (Type I Galactosemia; MIM 230400), the second enzyme of the Leloir pathway, have been associated with potentially lethal consequences ${ }^{13}$. The exact pathomechanism responsible for these differences remains to be fully elucidated; however, accumulated evidence suggests that the dysfunction of this essential metabolic pathway, rather than the presence of galactose, is a mediator of the phenotypic expression of the disorder. For example, the build-up of galactose, galactitol, and galactonate has been reported in both GALK and GALT deficiency; however, patients suffering from Type I Galactosemia also accumulate galactose-1-phosphate (GAL-1-P) making it a potential molecular suspect responsible for the development of the pathological phenotype ${ }^{11}$. Even though the mechanism of toxicity of GAL-1-P remains a topic of debate, some authors suggest that competition with glucose-1-phosphate (GLC-1-P) for UTP-glucose-1phosphate uridylyltransferase (UGP; EC 2.7.7.9) might lead to reduced availability of UDP-glucose substrates for UDP-glucose 4-epimerase (GALE; EC 5.1.3.2) further reducing UDP-galactose formation by impairment of a compensatory mechanism preserving regulatory lipid and protein glycosylation patterns in GALT-deficient cells ${ }^{14}$. Clinical findings on low-dose galactose supplementation in children with Type I Galactosemia further illustrate the complex pathophysiology underlying the disruption of galactose metabolism, as diet liberalization paradoxically restores $\mathrm{N}$-glycosylation of IgG in a subset of patients, providing the theoretical groundwork for clinical improvement that remains to be confirmed ${ }^{15}$.

Another significant field of research that generated a considerable amount of information on the effects of galactose is the study of senescence where chronic parenteral galactose treatment has been used for decades 
bioRxiv preprint doi: https:/doi.org/10.1101/2021.03.08.434370; this version posted March 8, 2021. The copyright holder for this preprint (which was not certified by peer review) is the author/funder, who has granted bioRxiv a license to display the preprint in perpetuity. It is made available under aCC-BY-NC-ND 4.0 International license.

102

103

104

105

106

107

108

for induction of oxidative stress-associated organismic degeneration. Interestingly, although a substantial number of studies take advantage of the model for the research of anti-aging therapeutics ${ }^{16}$, research focused on the elucidation of the pathophysiological background of galactose-induced senescence is scarce. Oxidative stress has been proposed as the main mechanism responsible for galactose-induced aging in rodents ${ }^{16}$, however, the exact mechanism has never been clarified. Two recent comprehensive reviews on galactose-induced aging ${ }^{17}$ and neurodegeneration ${ }^{18}$ propose three main mechanisms responsible for the pathophysiological effects of parenteral galactose. One potential explanation of galactose-induced oxidative stress suggests galactose metabolism generates a substantial amount of the alcohol galactitol through a reaction catalyzed by aldehyde reductase (AR; EC 1.1.1.21) with consequent depletion of the reduced form of nicotinamide adenine dinucleotide phosphate (NADPH) and osmotic stress, as accumulated galactitol cannot be further metabolized ${ }^{17-20}$. Moreover, it has been proposed that generation of Amadori products and Schiff bases by the reaction of galactose with free amino acid groups of proteins, lipids, and nucleic acid with consequent rearrangements producing advanced glycation end products (AGE) plays an important pathophysiological role ${ }^{17,18}$. The third important mechanism suggests galactose generates $\mathrm{H}_{2} \mathrm{O}_{2}$ by undergoing an oxidation reaction catalyzed by galactose oxidase (GO; EC 1.1.3.9 $)^{17,18}$ and some researchers suggest that this is, in fact, the only metabolic route of galactose that produces reactive oxygen species $(\mathrm{ROS})^{21}$. Interestingly, although a substantial number of researchers working with galactose-induced models of aging in rodents refer to GO-mediated generation of $\mathrm{H}_{2} \mathrm{O}_{2}$ as an important mechanism explaining the detrimental effects of galactose ${ }^{17,18,22-34}$, this is a fungal enzyme that doesn't exist in rodents which makes these strong claims slightly suspicious as addressed in our recent comment ${ }^{35}$.

At the moment, questions of dose- and time-response effects, as well as differences in regards to the route of galactose administration and region-dependent metabolic capacities remain largely unaddressed, even though their implications are obvious and essential for understanding both the physiological and the pathophysiological significance of galactose treatment-related findings in the literature. In contrast to cognitive deterioration induced by chronic parenteral galactose administration to healthy rodents ${ }^{36,37}$, we have found that galactose dissolved in drinking water $\left(200 \mathrm{mg} / \mathrm{kg} /\right.$ day) available ad libitum, can both prevent ${ }^{8}$ and rescue ${ }^{38}$ cognitive deficits in a rat model of sporadic Alzheimer's disease induced by intracerebroventricular administration of streptozotocin (STZ-icv). Chogtu et al. reported both oral and subcutaneous galactose beneficially affect memory and learning; however, the observed effect was dependent on the duration of the treatment ${ }^{39}$. On the other 
bioRxiv preprint doi: https:/doi.org/10.1101/2021.03 08.434370; this version posted March 8,2021 . The copyright holder for this preprint (which was not certified by peer review) is the author/funder, who has granted bioRxiv a license to display the preprint in perpetuity. It is made available under aCC-BY-NC-ND 4.0 International license.

130 hand, Budni et al. reported that even oral galactose treatment has the potential to induce cognitive impairment

131 and oxidative damage in rats when given by oral gavage in a bolus dose once per day at relatively low doses (100 $\mathrm{mg} / \mathrm{kg})^{40}$

Our research aimed to analyze the acute effects of a single dose of galactose administered by oral gavage. As

134 oxidative stress is considered to be the main mediator of pathophysiological effects, we focused on the redox

135 regulatory network (RRN), a set of intertwined subcellular systems responsible for the regulation of oxidantantioxidant balance. We were especially interested in the cellular response to galactose-induced oxidative stress

137 because oxidative stress has been recognized as an important mediator of hormesis ${ }^{41}$ - a dose-response 138 phenomenon where low-dose stimulation with tolerable noxious stimulus provides long-term protection 139 through the upregulation of protective cellular machinery. We hypothesized that acute responses of systemic

140 RRN reflected by plasma mediators would help us understand whether even short-term increases of systemic 141 galactose availability could induce redox disbalance before adaptive responses are activated. Moreover, we were 142 interested in the response of hippocampal RRN, as the hippocampus (HPC) is considered to be one of the biological targets responsible for parenteral galactose-induced cognitive deficits. 


\section{Materials and Methods}

145

146

147

\section{Galactose treatment and experimental design}

153

\section{Animals} chip bedding was changed twice per week. point galactose metabolism in target tissues is taking place.

\section{Tissue collection and preparation}

Three-month-old male Wistar rats with a mean weight of $372 \mathrm{~g}$ (SD: 30) from the animal facility at the Department of Pharmacology (University of Zagreb School of Medicine) were used in the experiment. Animals were housed 2-3 per cage with a $12 \mathrm{~h}$ light/dark cycle $(7 \mathrm{am} / 7 \mathrm{pm})$. Room temperature and humidity were in the range of $21-23^{\circ} \mathrm{C}$ and $40-70 \%$, respectively. Food pellets and water were available ad libitum. Standard wood-

Animals were assigned to control (CTR) or one of galactose treatment groups (GAL 0.5h, GAL $1 \mathrm{~h}$, or GAL $2 \mathrm{~h}$ ) in a randomized order ( 8 animals/group). CTR received no galactose treatment and was used as baseline control and groups GAL 0.5h, GAL $1 \mathrm{~h}$, and GAL $2 \mathrm{~h}$ received galactose solution by orogastric gavage (1 $\mathrm{ml}$ of $200 \mathrm{mg} / \mathrm{kg}$ galactose dissolved in water) and were sacrificed either 30,60, or 120 minutes after the treatment respectively. Treatment dose was chosen based on our previous research ${ }^{8,38,42}$. Time-points were chosen based on previous findings that galactose plasma concentration is increased 15 minutes after both peroral and intraperitoneal treatment in both STZ-icv ${ }^{38}$ and control animals [unpublished data], and that this increment is resolved 30 minutes after peroral administration of $200 \mathrm{mg} / \mathrm{kg}$ solution (see Fig 2B) indicating that at approximately this time

Animals (6/group) were euthanized in general anesthesia (ketamine $50 \mathrm{mg} / \mathrm{kg} /$ xylazine $5 \mathrm{mg} / \mathrm{kg}$ ip) and decapitated. The brains were quickly removed and the hippocampi dissected, frozen in liquid nitrogen, and stored at $-80^{\circ} \mathrm{C}$. Afterward, the samples were subjected to three cycles of sonification (Microson Ultrasonic Cell Disruptor XL, Misonix, SAD) in five volumes of lysis buffer containing $10 \mathrm{mM} \mathrm{HEPES,} 1 \mathrm{mM} \mathrm{EDTA}, 100 \mathrm{mM} \mathrm{KCl}, 1 \%$ Triton X-100, protease inhibitor cocktail (Sigma-Aldrich, USA) and phosphatase inhibitor (PhosSTOP, Roche, Switzerland) $(\mathrm{pH} 7.5)$ on ice. Homogenates were centrifuged for 10 minutes at $12000 \mathrm{RPM}$ and $4^{\circ} \mathrm{C}$. The protein concentration of supernatant for further analytical normalization was measured utilizing Lowry protein assay ${ }^{43}$ 
bioRxiv preprint doi: https:/doi.org/10.1101/2021.03 08 434370; this version posted March 8,2021 . The copyright holder for this preprint (which was not certified by peer review) is the author/funder, who has granted bioRxiv a license to display the preprint in perpetuity. It is made available under aCC-BY-NC-ND 4.0 International license.

172 and supernatants were stored at $-80^{\circ} \mathrm{C}$ until further analysis. The remaining animals (2/group) were subjected to

173 deep anesthesia and transcardially perfused with $250 \mathrm{ml}$ of saline followed by $250 \mathrm{ml}$ of $4 \%$ paraformaldehyde

$174\left(\mathrm{pH}\right.$ 7.4). Brains were quickly removed, cryoprotected through a series of sucrose (15\%-30\%), and stored at $-80^{\circ} \mathrm{C}$

175 until further analysis. Cerebrospinal fluid (CSF) and plasma were extracted in deep anesthesia before

176 decapitation or transcardial perfusion in all animals. CSF was sampled from the cisterna magna with a $330 \mu \mathrm{m}$

177 insulin needle in fixed cervical flexion. Plasma was extracted from whole blood drawn from the retro-orbital sinus

178 after centrifugation at $3600 \mathrm{RPM}$ at $4^{\circ} \mathrm{C}$ for 10 minutes in heparinized tubes (100 $\mu$ l per sample).

\section{Redox regulatory network analysis}

181 To fully understand the effects of oral galactose-induced oxidative stress, we focused on redox regulatory 182 network (RRN) subsystems. The superoxide detoxification subsystem (Fig1A) was analyzed by 1,2,3183 trihydroxybenzene autooxidation inhibition, the peroxidation subsystem (Fig1B) was analyzed by $\left[\mathrm{Co}\left(\mathrm{CO}_{3}\right)_{3}\right] \mathrm{Co}-$ derived $\mathrm{H}_{2} \mathrm{O}_{2}$ dissociation rate and luminol chemiluminescence assay, lipid peroxidation (Fig1C) was measured by TBARS, low molecular weight thiols (LMWT) (Fig1D) were determined by TNB quantification after molecular weight fractionation, protein sulfhydryl content (Fig1E) was calculated from the protein-DTNB reaction, and the quantification (Fig1F). 


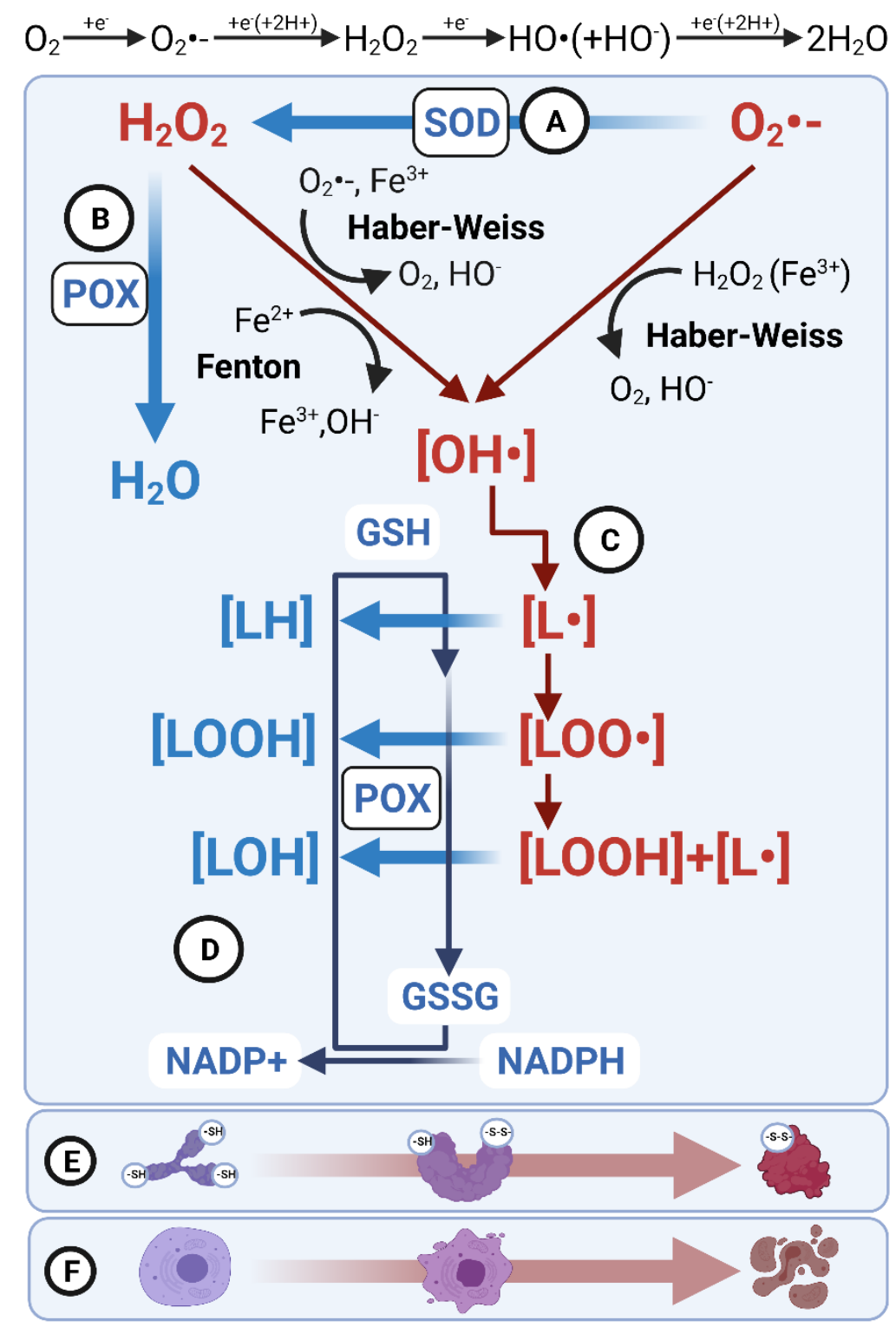

Fig. 1 A simplified schematic overview of the most important cellular redox regulatory network subsystems 
bioRxiv preprint doi: https:/doi.org/10.1101/2021.03.08.434370; this version posted March 8, 2021. The copyright holder for this preprint (which was not certified by peer review) is the author/funder, who has granted bioRxiv a license to display the preprint in perpetuity. It is made available under aCC-BY-NC-ND 4.0 International license.

molecular oxygen. Dismutation of superoxide produces hydrogen peroxide $\left(\mathrm{H}_{2} \mathrm{O}_{2}\right)$ an important endogenously produced reactive oxygen species (ROS) involved not only in ROS-mediated cellular damage but also in adaptor signaling. Cellular $\mathrm{H}_{2} \mathrm{O}_{2}$ is under the control of peroxidases (B), a large group of enzymes that break down different cellular peroxides. One of the most important ubiquitously present peroxidases is catalase, an enzyme that catalyzes the decomposition of $\mathrm{H}_{2} \mathrm{O}_{2}$ to oxygen and water. $\mathrm{Both}_{2} \mathrm{O}_{2}$ and $\mathrm{O}_{2} \bullet$ - have the potential to generate hydroxyl radicals $(\mathrm{OH} \bullet)$ that in turn have the potential to generate lipid radicals $(L \bullet)$, lipid peroxy radicals $(\mathrm{LOO} \bullet)$ and damaging lipid hydroperoxides (LOOH)(C). Glutathione peroxidases are a major cellular defense system against the generation and propagation of lipid radicals. Glutathione peroxidase catalyzes both the reduction of $\mathrm{H}_{2} \mathrm{O}_{2}$ to water and the reduction of other peroxide radicals (e.g. lipid hydroperoxides) to alcohols and water. Glutathione peroxidases rely on cellular stores of monomeric glutathione (GSH), the most important low molecular cellular antioxidant that gets converted to a glutathione disulfide in the process (GSSG). Monomeric glutathione stores are then replenished by glutathione reductases that rely on the pool of reduced fraction of nicotinamide adenine dinucleotide phosphates NADPH to reduce glutathione disulfides (D). Cellular proteins with abundant free sulfhydryl groups are involved in buffering excessive cellular ROS and it has been shown that this buffer pool has functional consequences (E). For example, as briefly discussed in the text, glyceraldehyde 3phosphate dehydrogenase, an important metabolic enzyme serves the role of pleiotropic molecular regulator integrating ROS sensing with cellular metabolism by forming intramolecular disulfides at active site cysteines, rendering the cell able to reroute substrates during the excessive ROS formation, and rapidly resume metabolic activity after oxidative stress subsides. On the other hand, excessive oxidative stress denatures proteins yielding an irreversible loss of function. Finally, at the cellular level, the harmonized function of the aforementioned redox-regulatory subsystems orchestrates the cellular fate when exposed to ROS-generating noxious stimulus. Low levels of oxidative stress that can be successfully compensated usually provoke adaptor response of the cell while excessive oxidative stress or moderate noxious stimulus in combination with a reduced capacity of one or several defense systems leads to the collapse of regulatory systems and results in cell death. 
bioRxiv preprint doi: https:/doi org/10.1101/2021.03.08.434370; this version posted March 8,2021 . The copyright holder for this preprint (which was not certified by peer review) is the author/funder, who has granted bioRxiv a license to display the preprint in perpetuity. It is made available under aCC-BY-NC-ND 4.0 International license.

lodine solutions $\left(0.1 \mathrm{M} \mathrm{I}_{2}\right.$ and $\left.0.4 \mathrm{M} \mathrm{KI}\right)$ were used as the redox pair electrode solution in the experiment ${ }^{45}$. In short, $5 \mu \mathrm{L}$ of hippocampal homogenate was mixed with $5 \mu \mathrm{L}$ of the redox pair electrode solution and $40 \mu \mathrm{L}$ of ddH2O. Samples were kept in the dark for 1 hour at room temperature. The reductive potential was measured with a $6230 \mathrm{~N}$ Microprocessor meter (Jenco Instruments, San Diego, USA) coupled with a redox microsensor system ORP-146S (Shelf Scientific, Lazar Research Laboratories, USA). The system was composed of a Pt sensing element and $\mathrm{Ag} / \mathrm{AgCl}$ reference with a fluoropolymer-based reference junction and capillary. $\mathrm{KCl}$ was used as a filling solution. The system was battery-powered during all measurements to exclude potential powerline interference. The oxidation-reduction potential measurement range was $-1500 \mathrm{mV}$ to $+1500 \mathrm{mV}$ with a system accuracy of $\pm 0.5 \mathrm{mV}$.

\section{Hydrogen peroxide dissociation rate}

Catalase and peroxidase activity was determined indirectly by hydrogen peroxide dissociation rate. In short, samples were vortexed and $30 \mu \mathrm{L}$ of each sample was placed in a 96-well plate. Sample background absorbance was checked at 450 and $560 \mathrm{~nm}$ to control for internal interference. $\mathrm{H}_{2} \mathrm{O}_{2}$ concentration was determined by oxidation of cobalt (II) to cobalt (III) in the presence of bicarbonate ions by spectrophotometric quantification of carbonato-cobaltate (III) complex $\left(\left[\mathrm{Co}\left(\mathrm{CO}_{3}\right)_{3}\right] \mathrm{Co}\right)$ at a $450 \mathrm{~nm}$ peak. Reference absorbance for each sample was estimated by baseline $\mathrm{H}_{2} \mathrm{O}_{2}$ quantification at $t_{0}=0 \mathrm{~s}$, and final absorbance was determined at $t_{1}=120 \mathrm{~s}$. The reaction was started by adding $40 \mu \mathrm{L}$ of $\mathrm{H}_{2} \mathrm{O}_{2}$ solution (10 mM in 1xPBS) and stopped by adding $100 \mu \mathrm{L}$ of cobalt (II) hexametaphosphate working solution as previously described by Hadwan ${ }^{46}$. Absorbance was measured with Infinite F200 PRO multimodal microplate reader (Tecan, Switzerland).

\section{Superoxide dismutase activity}

Superoxide dismutase activity was measured by 1,2,3-trihydroxybenzene autooxidation inhibition ${ }^{47}$. In short, 15 $\mu \mathrm{L}$ of $60 \mathrm{mM}$ 1,2,3-trihydroxybenzene dissolved in $1 \mathrm{mM} \mathrm{HCl}$ was added to $1000 \mu \mathrm{L}$ of $0.05 \mathrm{M}$ Tris- $\mathrm{HCl}$ and $1 \mathrm{mM}$ $\mathrm{Na}_{2}$ EDTA ( $\mathrm{pH} 8.2$ ), briefly vortexed and mixed with $10 \mu \mathrm{L}$ of hippocampal homogenate. Absorbance increase was recorded at $325 \mathrm{~nm}$ for 300 seconds. Maximal 1,2,3-trihydroxybenzene autooxidation was determined by the same procedure without adding the tissue sample. Autooxidation inhibition was calculated as a ratio of sample and reference sample difference in end-point and baseline absorbance, ratiometrically corrected for tissue 
bioRxiv preprint doi: https:/doi org/10.1101/2021.03.08.434370; this version posted March 8,2021 . The copyright holder for this preprint (which was not certified by peer review) is the author/funder, who has granted bioRxiv a license to display the preprint in perpetuity. It is made available under aCC-BY-NC-ND 4.0 International license.

\section{Cytochrome c-mediated peroxide dissociation} DoubleBeam UV-Visible Spectrophotometer (Cambridge, UK). ratiometrically corrected for sample protein concentration.

\section{Lipid peroxidation} sample protein concentration.

sample protein concentration. Continuous change in absorbance was determined by CamSpec M350

\section{Low molecular weight thiols and total protein sulfhydryl content}

Low molecular weight thiols (LMWT) and tissue protein sulfhydryl content were assessed by the formation of 5thio-2-nitrobenzoic acid (TNB) in a reaction between sulfhydryl groups and 5,5'-dithio-bis(2-nitrobenzoic acid)

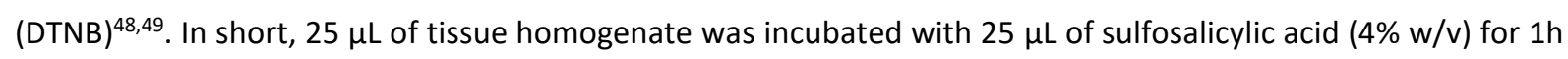
on ice and centrifuged for 10 minutes at 10000 RPM. The supernatant ( $30 \mu \mathrm{L})$ was transferred to separate tubes for LMWT determination. The protein pellet was mixed with $30 \mu \mathrm{L}$ of DTNB ( $4 \mathrm{mg} / \mathrm{ml}$ in $5 \%$ sodium citrate) and $540 \mu \mathrm{L} \mathrm{KPB}(0.1 \mathrm{M}, \mathrm{pH} 7.4)$, and the mixture absorbance was read at $412 \mathrm{~nm}$ for total protein sulfhydryl content determination. The remaining supernatant was added to the same DTNB reagent and KPB and its absorbance measured at $412 \mathrm{~nm}$ were used for LMWT estimation. Absorbance was determined by CamSpec M350 DoubleBeam UV-Visible Spectrophotometer (Cambridge, UK). The calculated sulfhydryl content was

Lipid peroxidation was estimated employing standard malondialdehyde assay based on the determination of thiobarbituric acid reactive substances (TBARS) ${ }^{48}$. In short, $36 \mu \mathrm{L}$ of tissue homogenate was mixed with $400 \mu \mathrm{L}$ TBARS-TCA reagent $\left(0,375 \%\right.$ thiobarbituric acid; $15 \%$ trichloroacetic acid) and $164 \mu \mathrm{L}$ of ddH $\mathrm{d}_{2} \mathrm{O}$. Samples were incubated at $95^{\circ} \mathrm{C}$ for 20 minutes in perforated Eppendorf tubes and left to cool down under tap water. The complex of thiobarbituric acid and malondialdehyde was extracted by adding $600 \mu \mathrm{L}$ of n-butanol to the mixture. The absorbance of the butanol fraction was analyzed at $532 \mathrm{~nm}$ and the amount of TBARS was estimated based on the molar extinction coefficient of $1,56 \times 10^{5} \mathrm{M}^{-1} \mathrm{~cm}^{-1}$. Absorbance was determined by CamSpec M350 DoubleBeam UV-Visible Spectrophotometer (Cambridge, UK). Calculated TBARS content was corrected for 
bioRxiv preprint doi: https:/doi.org/10.1101/2021.03.08.434370; this version posted March 8,2021 . The copyright holder for this preprint (which was not certified by peer review) is the author/funder, who has granted bioRxiv a license to display the preprint in perpetuity. It is made available under aCC-BY-NC-ND 4.0 International license.

Cytochrome c-mediated hydrogen peroxide dissociation was quantified by native sodium dodecyl sulfatepolyacrylamide gel electrophoresis (SDS-PAGE) followed by membrane chemiluminiscence ${ }^{50}$. The protocol was the same as described for western blot, with the omission of heating at $95^{\circ} \mathrm{C}$ during sample preparation. After electrophoretic separation and transfer, the nitrocellulose membrane was incubated in an enhanced chemiluminescence reagent (SuperSignal ${ }^{\mathrm{TM}}$ West Femto; Thermo Fisher Scientific, USA). Luminescence was captured by MicroChemi high-performance chemiluminescence imager (DNR Bio-Imaging Systems Ltd., Israel) and GelCapture software. The consequent analysis was the same as described for Western blot.

\section{Western blot}

Protein expression of c-fos and GALK1 was measured by Western blot with subsequent chemiluminescent-based quantification. Equal amounts of total protein $(35 \mu \mathrm{g})$ determined by the Lowry assay were separated by SDSPAGE (9\% polyacrylamide gels) and transferred to nitrocellulose membranes using the wet transfer $(100 \mathrm{~V} / 400 \mathrm{~mA} / 60 \mathrm{~min}$ in $140 \mathrm{mM}$ glycine, $18 \mathrm{mM}$ Tris, 20\% methanol $(\mathrm{v} / \mathrm{v}))$. Nitrocellulose membranes were incubated in blocking buffer (5\% nonfat dry milk solution with 0,5\% Tween 20 in low-salt washing buffer (LSWB: $10 \mathrm{mM}$ Tris, $150 \mathrm{mM} \mathrm{NaCl}, \mathrm{pH}$ 7.5)) for $1 \mathrm{~h}$ at room temperature. Blocked membranes were incubated in c-fos (1:000, Cell Signaling Technology, USA) or GALK1 (1:1000, Invitrogen, USA) primary antibody solution in blocking buffer overnight at $4^{\circ} \mathrm{C}$. After incubation, membranes were washed $3 \mathrm{x}$ in LSWB and incubated with anti-rabbit IgG secondary antibody (1:2000, Cell Signaing Technology, USA) in blocking buffer. Membranes were washed 3x in LSWB and incubated in chemiluminescent reagent (SuperSignal ${ }^{\text {TM }}$ West Femto; Thermo Fisher Scientific, USA). Luminescence was captured by MicroChemi high-performance chemiluminescence imager (DNR Bio-Imaging Systems Ltd., Israel) and GelCapture software. The same procedure was repeated for $\beta$-actin (1:2000, SigmaAldrich, USA) used as a loading control. Immunoblot densitometry was done in Fiji (NIH, USA) using Gel Analyzer protocol after Rolling Ball background subtraction. 
bioRxiv preprint doi: https:/doi org/10.1101/2021.03.08.434370; this version posted March 8,2021 . The copyright holder for this preprint (which was not certified by peer review) is the author/funder, who has granted bioRxiv a license to display the preprint in perpetuity. It is made available under aCC-BY-NC-ND 4.0 International license.

304

305

306

\section{Nitrocellulose redox permanganometry}

Nitrocellulose redox permanganometry (NRP) ${ }^{51}$ was used for reductive potential determination in plasma and hippocampal homogenates. HistoNRP was used for the reductive potential analysis of brain tissue cryosections. In short, plasma samples were centrifuged and $1 \mu \mathrm{L}$ of each sample was placed onto a clean piece of nitrocellulose membrane (Amersham Protran 0.45; GE Healthcare Life Sciences, USA) and left to dry out. Once dry, the

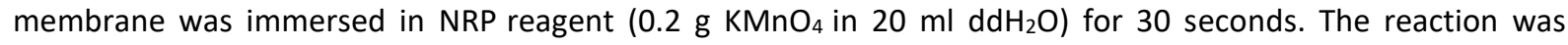
terminated and $\mathrm{MnO}_{2}$ contrast was developed by placing the membrane under running $\mathrm{ddH}_{2} \mathrm{O}$. For the HistoNRP experiment, we used $30 \mu \mathrm{m}$ thick brain cryosections (Leica CM1850; Leica Biosystems, USA). In short, sections were mounted onto microscope slides and tissue proteins were transferred onto nitrocellulose by passive diffusion slice print blotting protocol with PBS as a transfer buffer. The transfer was conducted overnight under the constant pressure of $31.384 \mathrm{mmHg}$. Membranes were carefully removed with PBS, left to dry out, and reacted with NRP solution using the same protocol as described above. All membranes were digitalized by an office scanner (SP 4410SF, RICOH, USA) and analyzed in Fiji (NIH, USA) as described in detail in ${ }^{51}$.

\section{Total NADP and NADPH measurement}

Total NADP and NADPH in hippocampal homogenates were measured colorimetrically using NADP/NADPH Quantitation kit (Sigma-Aldrich, USA) following the manufacturer's instructions. Absorbance was read with Infinite F200 PRO multimodal microplate reader (Tecan, Switzerland).

\section{Glutamate quantification}

Glutamate quantity in hippocampal homogenates $(10 \mu \mathrm{l})$ was measured colorimetrically utilizing Glutamate Assay Kit (Sigma-Aldrich, USA) following the manufacturer's instructions. Absorbance at $450 \mathrm{~nm}$ was read with Infinite F200 PRO multimodal microplate reader (Tecan, Switzerland). 
bioRxiv preprint doi: https://doi.org/10.1101/2021.03 08 434370; this version posted March 8,2021 . The copyright holder for this preprint (which was not certified by peer review) is the author/funder, who has granted bioRxiv a license to display the preprint in perpetuity. It is made available under aCC-BY-NC-ND 4.0 International license.

330

331

332

333

334

335

\section{Plasma glucose and galactose measurement}

Glucose was measured in $10 \mu \mathrm{l}$ of plasma sample colorimetrically with the standard Trinder method utilizing glucose oxidase and 4-amino-antipyrine provided in a commercial kit (Greiner Diagnostic, Germany). Plasma galactose was determined with the Amplex ${ }^{\mathrm{TM}}$ Red Galactose/Galactose Oxidase Assay Kit (Thermo Fisher Scientific, USA) following the manufacturer's instructions. Absorbance was read at $570 \mathrm{~nm}$ with Infinite F200 PRO multimodal microplate reader (Tecan, Switzerland).

\section{Data analysis and visualization}

Data analysis and visualization were conducted in $\mathrm{R}$ (4.0.2). As our experiment was exploratory raw data was reported for all variables measured both in plasma and hippocampal homogenates. The association of variables of interest was explored by principal component analysis on scaled and mean-imputed datasets and reported as a biplot of individual animals. Individual variables and their contributions to the $1^{\text {st }}$ and $2^{\text {nd }}$ dimension were reported as vectors in the biplot space with color and length signaling contributions. Coordinates of individual animals in the biplot space were used for post-hoc group comparisons. The Wilcoxon signed-rank test was used as a non-parametric test for the comparison of two groups with an alpha set at $5 \%$. 
Results:

\section{The effect of acute oral galactose treatment on plasma redox regulatory network}

following the assumption that widespread systemic oxidative stress should be mirrored by plasma redox status.

$2 \mathrm{~h} ; \mathrm{p}=0.13)$ (Fig2B). Interestingly, in contrast to what we expected, lipid peroxidation end products were reduced potential showed a trend of increment after galactose treatment with no statistical significance (CTR vs GAL; $\mathrm{p}=0.15)$ (Fig2D). Another marker of reductive potential, NRP, was also unchanged with a slight trend of increment only in GAL $2 \mathrm{~h}$ in comparison to GAL $1 \mathrm{~h}(\mathrm{p}=0.14)$ (Fig2E). Finally, we measured plasma glucose to assess how single oral galactose treatment effects were related to glucose perturbations, with no significant changes being detected in analyzed time points (Fig2F). Furthermore, no difference in plasma galactose concentration was observed, indicating the administered galactose was fully absorbed and/or metabolized by target organs in the first 30 minutes (Fig2G). Overall, apart from reduced lipid peroxidation, none of the measured parameters indicated acute oral galactose treatment in the dose of $200 \mathrm{mg} / \mathrm{kg}$ was able to perturb rat systemic redox regulatory network. Multivariate analysis of measured indicators revealed subtle clusters that described $31.2 \%$ and $25.5 \%$ of the variance in the $1^{\text {st }}$ and $2^{\text {nd }}$ dimensions respectively. Coordinates of individual animals in the biplot are shown in Fig $\mathbf{2 H}$, and the contribution of individual variables is depicted in Fig $\mathbf{2}$. Biplot coordinates of

368 individual animals classified by treatment in respect to the first two principal components are shown in Fig $2 \mathrm{~J}$, 
bioRxiv preprint doi: https://doi.org/10.1101/2021.03.08.434370; this version posted March 8, 2021. The copyright holder for this preprint (which was not certified by peer review) is the author/funder, who has granted bioRxiv a license to display the preprint in perpetuity. It is made available under aCC-BY-NC-ND 4.0 International license.

A

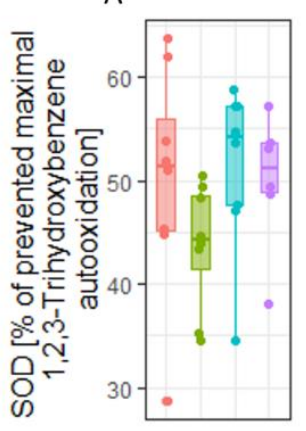

$\mathrm{F}$

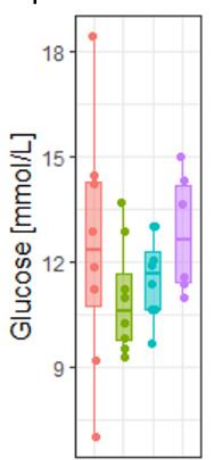

B

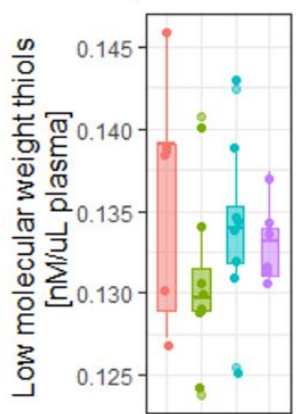

C

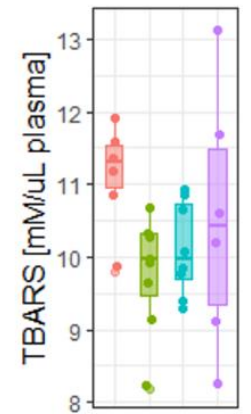

D

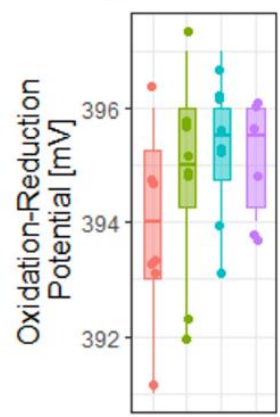

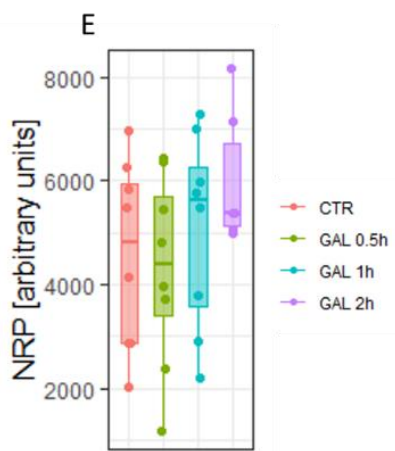

G

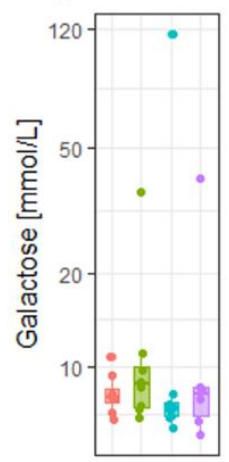

H

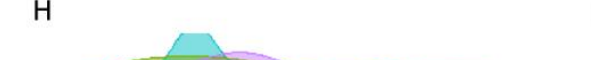

\section{।}

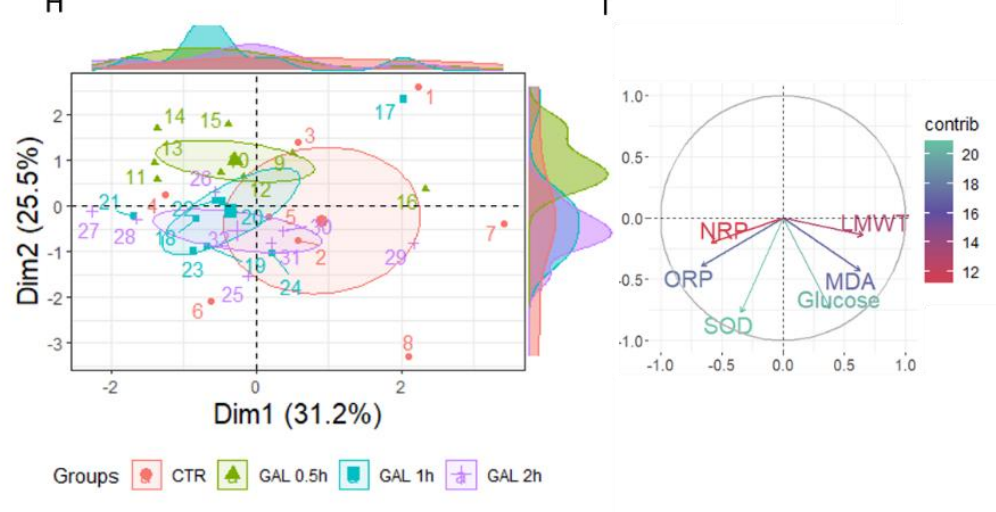

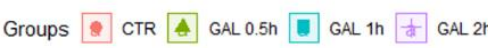

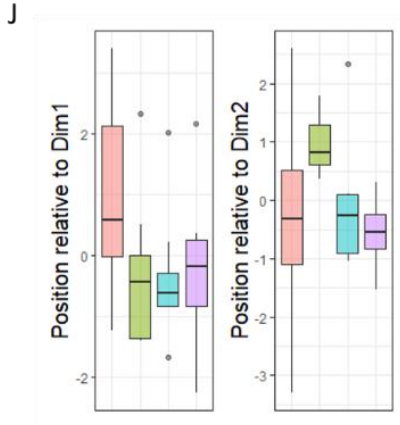

K

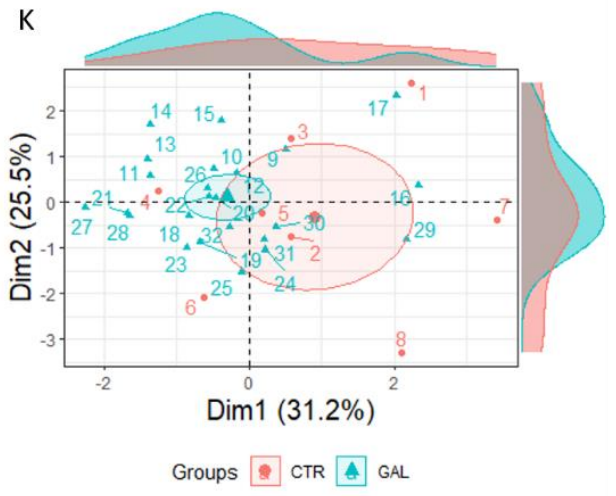

Fig 2. The effect of acute oral galactose treatment on the plasma redox regulatory network. The effect of acute oral galactose treatment on (A) the activity of superoxide dismutase (SOD)[CTR vs GAL $0.5 \mathrm{~h} p=.065$; GAL 0.g5 vs GAL 1h p=.052], (B) the concentration of low molecular weight thiols (LMWT), (C) lipid peroxidation reflected by the concentration of thiobarbituric acid reactive substances (TBARS) [CTR vs GAL $0.5 \mathrm{~h} p=.017$; CTR vs GAL $1 \mathrm{~h}$ $\mathrm{p}=.023]$, overall redox balance measured by (D) $\mathrm{I}_{2} / \mathrm{KI}$ redox couple-stabilized oxidation-reduction potential (ORP), and (E) nitrocellulose redox permanganometry (NRP). (F) The effect of acute oral galactose treatment on plasma glucose concentration [GAL $0.5 \mathrm{~h}$ vs GAL $2 \mathrm{~h} p=.053$ ]. (G) The effect of acute oral galactose treatment on plasma galactose concentration. (H) Principal component analysis biplot of the $1^{\text {st }}$ and $2^{\text {nd }}$ principal components with

381 individual animal coordinates. (I) Contribution of individual variables to the $1^{\text {st }}$ and $2^{\text {nd }}$ principal components with a contribution (\%) depicted by color and length of the vector. (J) Comparison of animals by groups based on 
bioRxiv preprint doi: https:/doi.org/10.1101/2021.03.08.434370; this version posted March 8, 2021. The copyright holder for this preprint (which was not certified by peer review) is the author/funder, who has granted bioRxiv a license to display the preprint in perpetuity. It is made available under aCC-BY-NC-ND 4.0 International license.

assigned appropriate coordinates in respect to the $1^{\text {st }}$ and $2^{\text {nd }}$ component respectively. (K) The "overall" effect of galactose demonstrated on the biplot shown in Fig 2G. CTR - control; GAL - galactose treated. * [Wilcoxon signed-rank comparisons].

\section{The effect of acute oral galactose treatment on hippocampal redox regulatory network}

We then moved on to examine RRN subsystems in the hippocampus. SOD activity was reduced in all groups after galactose treatment in comparison with controls (Fig3A). Peroxidase activity approximated from the $\mathrm{H}_{2} \mathrm{O}_{2}$ dissociation rate demonstrated an increasing trend reaching the highest values in the GAL 1h group (Fig3B). Here, we additionally tested cytochrome $\mathrm{C}_{2} \mathrm{O}_{2}$ dissociation activity and observed a similar trend with the highest activity in the GAL 1 h group [CTR vs GAL $1 \mathrm{~h} ; \mathrm{p}=0.043$ ] (Fig3C). LMWT concentration remained unchanged in all groups (Fig3D), but total protein-free sulfhydryl groups demonstrated a transient decrement upon treatment normalized over time [GAL 0.5h vs GAL 2h; $\mathrm{p}=0.037$ ] (Fig3E). Lipid peroxidation remained largely unchanged with a trend of increment observed only in GAL $1 \mathrm{~h}$ in comparison to GAL 0.5h [p=0.12] (Fig3F). We then moved on to examine the effect of oral galactose on the overall cellular redox balance. Based on the results obtained from the analysis of individual RRN subsystems (reduced SOD activity, increased peroxidase activities, possible transient reduction in total protein free sulfhydryl groups, and a trend towards increased lipid peroxidation) we expected to see the redox balance shifted towards a pro-oxidative state. Interestingly, in contrast to our expectations, ORP was reduced rather than increased in the GAL $1 \mathrm{~h}$ group, suggesting galactose treatment increased reductive capacity (Fig3G). Although ORP changes were consistent, the effect was small and we wanted to verify our findings; therefore, we performed an additional examination of the reductive potential using NRP, where the finding of an increased reduction potential after galactose treatment was confirmed (Fig3H). However, as ORP and NRP suggested a different pattern of reductive potential increment, we analyzed their correlation by linear regression, where we obtained a negative correlation, as expected $(R=-0.51 ; p=0.013)$. Interestingly, when treatment control was introduced to the model, the effect was preserved in the control group, but lost in galactose-treated rats (CTR: $R=-0.88 ; p=0.02 / G A L: R=-0.035 ; p=0.9$ ) suggesting that galactose treatment interfered with a reductive component of the system that enters a redox reaction with $\mathrm{KMnO}_{4}$ much more effectively than with the $\mathrm{I}_{2} / \mathrm{KI}$ redox pair used for ORP stabilization, as described in the Methods section (Fig 3I). To further explore the nature of this unexpected rise in the total reductive potential induced by acute oral 
bioRxiv preprint doi: https:/doi.org/10.1101/2021.03.08.434370; this version posted March 8, 2021. The copyright holder for this preprint (which was not certified by peer review) is the author/funder, who has granted bioRxiv a license to display the preprint in perpetuity. It is made available under aCC-BY-NC-ND 4.0 International license.

411

412

413

414

415

416

417

418

419

420

421

422

423

424

galactose treatment, we conducted a HistoNRP ${ }^{51}$ analysis on brain tissue cryosections. As shown in Fig4A and Fig4B, galactose induced an increase in overall brain reductive capacity in a time- and region-dependent manner, with the greatest values recorded in the GAL $1 \mathrm{~h}$ group, and with values in the GAL $2 \mathrm{~h}$ group being comparable to those recorded in the CTR group (or lower). As some differences in the regional distribution of the reductive potential increment were observed, a separate analysis of the specific brain areas of interest was conducted (Fig4C). Even though most of the analyzed brain areas demonstrated a similar pattern with a steady increment up to the GAL $1 \mathrm{~h}$ time-point and normalization or hyper compensation in the GAL $2 \mathrm{~h}$ time-point, some areas, such as the dorsal hippocampus and parietal cortex, demonstrated a steady progressive galactose-induced decrement of the reductive capacity, indicating a variable redox or metabolic tolerance to galactose throughout the brain (Fig4A, Fig4C). Interestingly, a different pattern was observed for the ventral and dorsal portions of the hippocampus indicating that different subsets of cells inside the same anatomical region could differ regarding the galactose metabolic tolerance. Especially high increment of reductive capacity was observed in substantia nigra, as evident both in Fig4A and Fig4C.

We then moved on to examine the possible background of the observed effect. Here, we focused on the NADP system for several reasons. It has been shown that acute oxidative stress challenge exerts a disinhibitory effect on the evolutionary conserved protective pentose phosphate pathway (PPP) metabolic network ${ }^{52-55}$. Moreover, galactose can enter PPP at various stages, and its conversion to glucose-6-phosphate provides a biochemical substrate for the oxidative branch of PPP. Furthermore, previous findings in activated T cells grown on galactosecontaining medium suggest galactose-derived glucose is shuttled into the PPP rather than the glycolytic pathway 56,57 and recent evidence shows that galactose, in contrast to glucose, doesn't activate the glycolytic gatekeeper

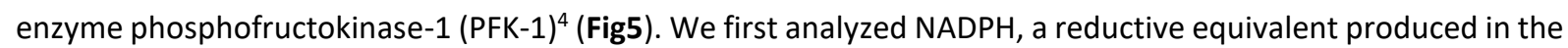
pentose phosphate pathway and used for regeneration of cellular antioxidant systems (Fig1C) and anabolic biosynthesis. As shown in Fig4D, NADPH concentration remained unchanged with a slight trend of increment after GAL treatment [CTR vs GAL; $p=0.14$ ]. However, analysis of total NADP revealed galactose treatment increased the concentration of total NADP by $542 \%$ [CTR vs GAL; $p=0.0017$ ] (Fig4E). Conversely, the ratio of reduced to total NADP fraction was decreased following galactose treatment (Fig4F) indicating increased utilization of reductive equivalents, possibly for the replenishment of cellular antioxidant systems and providing a potential explanation for the paradoxical pro-oxidant shift of some RRN subsystems with a simultaneous 
bioRxiv preprint doi: https:/doi.org/10.1101/2021.03 08 434370; this version posted March 8,2021 . The copyright holder for this preprint (which was not certified by peer review) is the author/funder, who has granted bioRxiv a license to display the preprint in perpetuity. It is made available under aCC-BY-NC-ND 4.0 International license.

439 increment of reductive capacity. We further hypothesized that the observed activation of the protective

440 oxidative pentose phosphate shunt would be followed by a reduction of cellular activity to compensate for the

441 reduced substrate flux into the lower glycolysis pathway and further decrease aerobic respiration-generated

442 ROS. To test this, we analyzed the expression of c-fos, a marker of neuronal activity, and found its expression to

443 be reduced by GAL treatment in a time-dependent manner (Fig4G). Moreover, we expected that acute galactose

444 treatment would induce the expression of galactokinase-1 (GALK1), an enzyme that catalyzes the first committed

445 step of the Leloir pathway as an adaptive response to increased galactose availability. As shown in Fig4H,

446 galactose treatment enhanced the expression of GALK1 in a time-dependent manner, with the increase being

447 most pronounced $2 \mathrm{~h}$ after the treatment [CTR vs GAL $2 \mathrm{~h} ;+222 \% ; \mathrm{p}=0.055$ ]. Furthermore, as it was previously suggested by Reutter and colleagues that one of the potential neuroprotective mechanisms of galactose might

449 be mediated by its ability to consume equivalents of ammonia, we additionally tested the effect of galactose on

450 the concentration of hippocampal glutamate and observed a rapid reduction with subsequent normalization

451 after $2 \mathrm{~h}$ (Fig4l). The association between individual metabolic and redox-related parameters was further explored by principal component analysis reported as a biplot with coordinates of individual animals classified

453 based on treatment group (Fig 4J) or the "overall effect of galactose treatment" (Fig 4K). Contribution of 454 individual parameters to the $1^{\text {st }}$ and $2^{\text {nd }}$ dimension are shown in Fig $\mathbf{4 L}$, and comparison of animals by groups based on assigned appropriate coordinates in Fig 4M. 
bioRxiv preprint doi: https://doi.org/10.1101/2021.03 08.434370; this version posted March 8,2021 . The copyright holder for this preprint (which was not certified by peer review) is the author/funder, who has granted bioRxiv a license to display the preprint in perpetuity. It is made available under aCC-BY-NC-ND 4.0 International license.
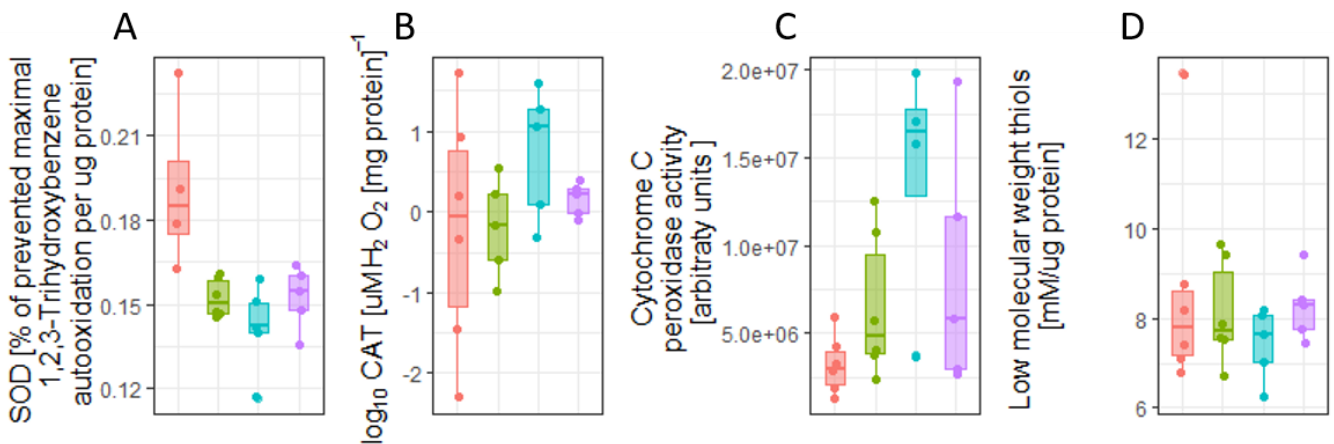

$\rightarrow$ CTR

$\rightarrow$ GAL $0.5 \mathrm{~h}$

$\rightarrow$ GAL $1 \mathrm{~h}$

$\rightarrow$ GAL $2 \mathrm{~h}$
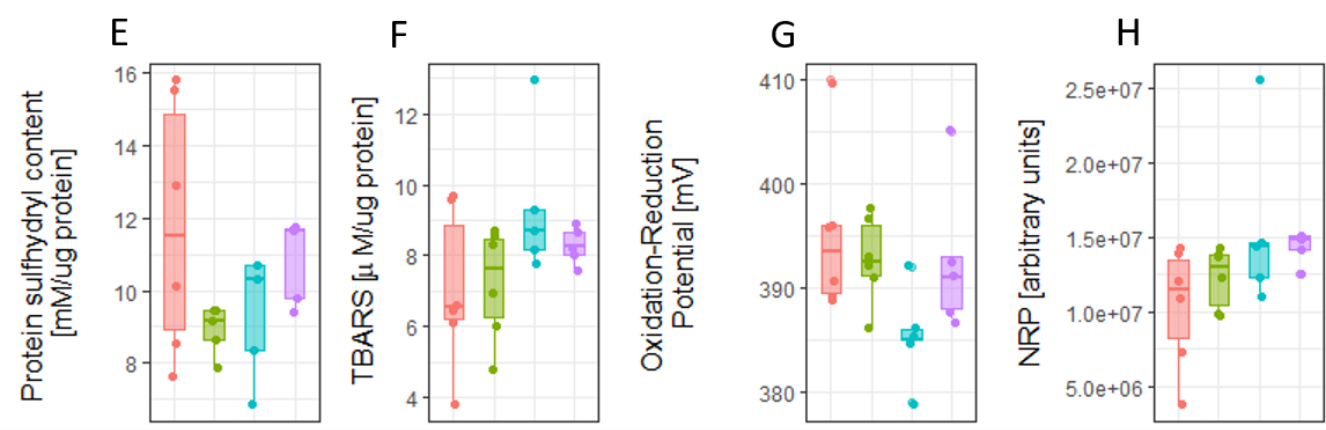

$\rightarrow$ CTR

$\rightarrow$ GAL $0.5 \mathrm{~h}$

- GAL 1h

- GAL 2h

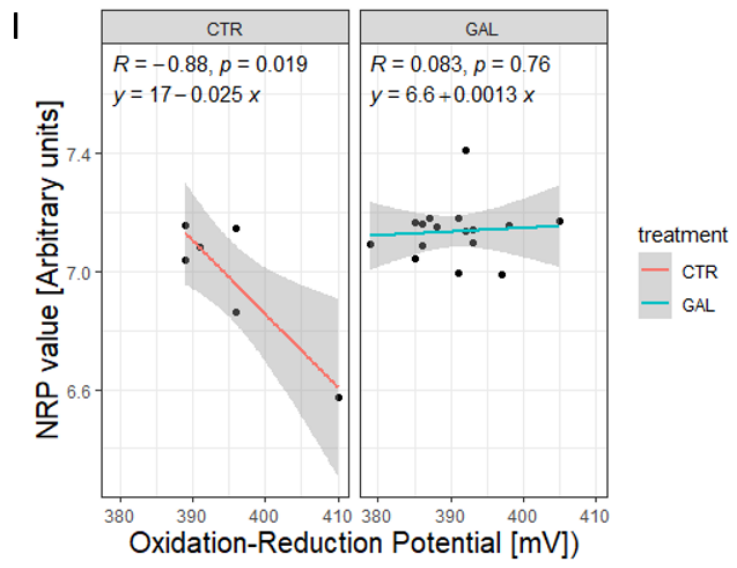

Fig 3. The effect of acute oral galactose treatment on the hippocampal redox regulatory network. The effect of acute oral galactose treatment on (A) the activity of superoxide dismutase (SOD)[CTR vs GAL $0.5 \mathrm{~h} p=.009$; vs GAL 1h $p=.016$; vs $\mathrm{GAL} 2 \mathrm{~h} \mathrm{p}=.032$ ], (B) $\mathrm{H}_{2} \mathrm{O}_{2}$ dissociation rate, (C) peroxidase-like activity of cytochrome c [CTR vs GAL 1h $\mathrm{p}=.038$ ], (D) low molecular weight thiols (LMWT), (E) protein free sulfhydryl groups [GAL $0.5 \mathrm{hh}$ vs GAL $2 \mathrm{~h}$ $\mathrm{p}=.032]$, (F) lipid peroxidation reflected by the concentration of thiobarbituric acid reactive substances (TBARS), and the overall redox balance measured by $(G) I_{2} / K I$ redox couple-stabilized oxidation-reduction potential (ORP) [GAL $1 \mathrm{~h}$ vs CTR $p=.035$; vs GAL $0.5 \mathrm{~h} p=.035$; vs GAL $2 \mathrm{~h} p=.059$ ], and $(\mathrm{H})$ nitrocellulose redox permanganometry 
bioRxiv preprint doi: https://doi.org/10.1101/2021.03 08.434370; this version posted March 8, 2021. The copyright holder for this preprint (which was not certified by peer review) is the author/funder, who has granted bioRxiv a license to display the preprint in perpetuity. It is made available under aCC-BY-NC-ND 4.0 International license.

A

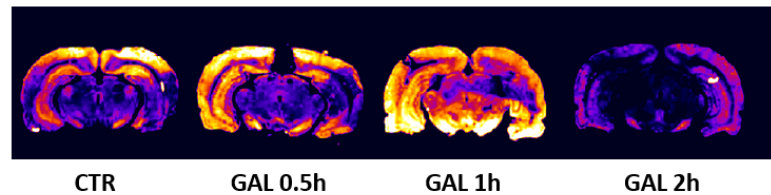

B

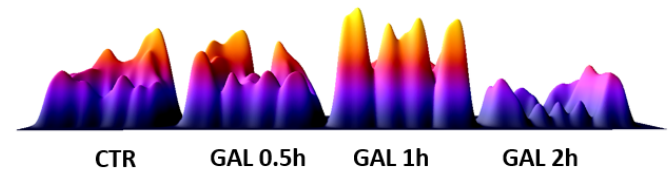

C
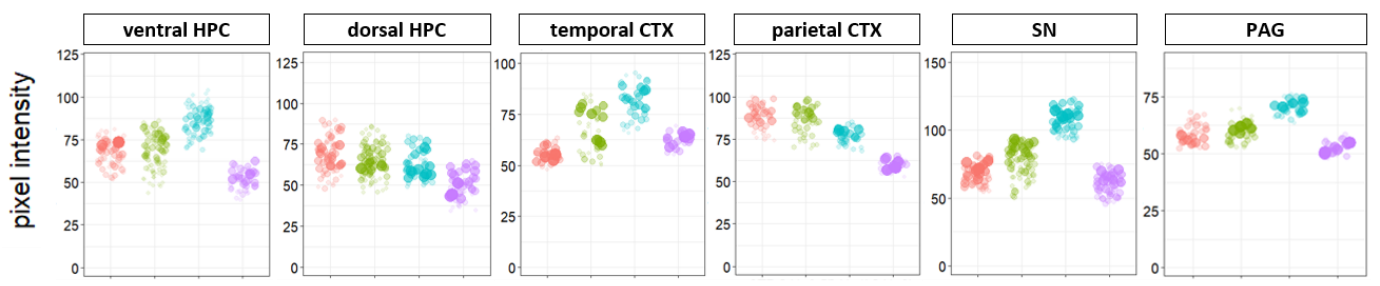

$\because$ CTR

$\rightarrow$ GAL $0.5 \mathrm{~h}$

$\rightarrow$ GAL $1 \mathrm{~h}$

$\rightarrow$ GAL $2 \mathrm{~h}$

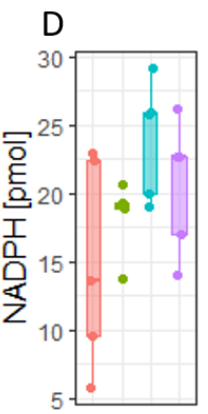

E

F
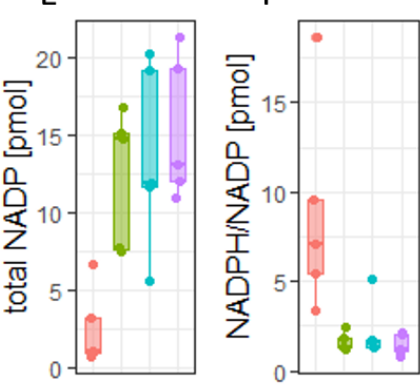

G

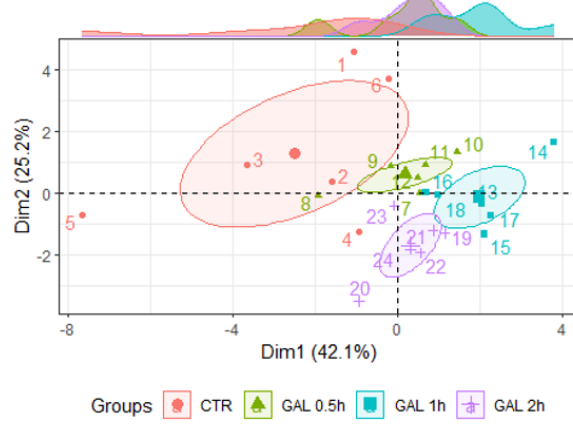

$\mathrm{L}$
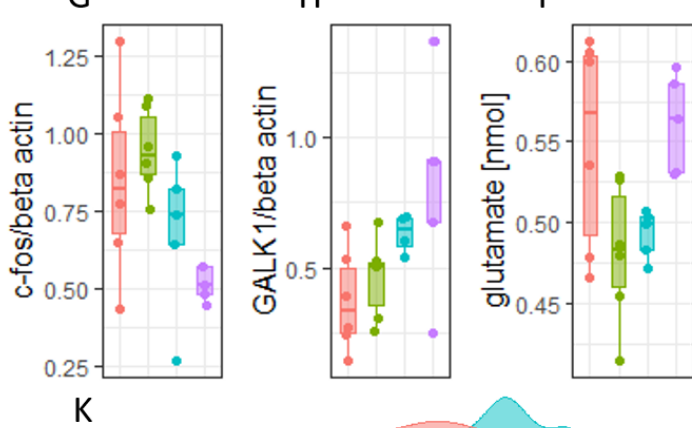

$\rightarrow$ CTR

$\rightarrow$ GAL 0.5h

$\rightarrow$ GAL 1h

$\rightarrow$ GAL $2 \mathrm{~h}$

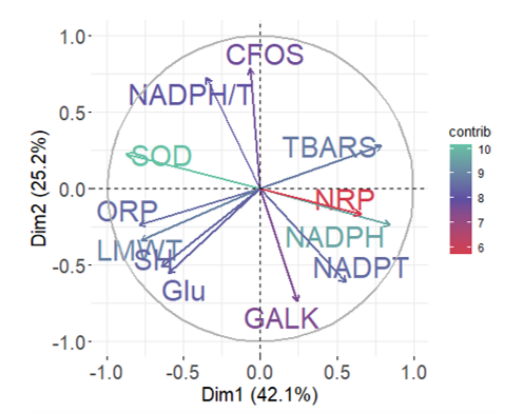

M

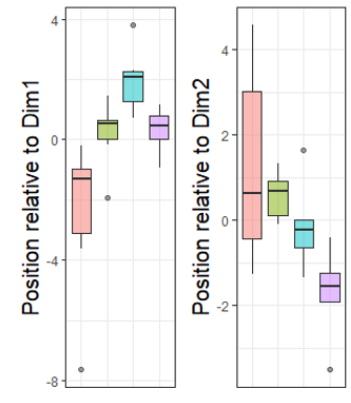

$\because$ CTR

$\rightarrow$ GAL $0.5 \mathrm{~h}$

$\rightarrow$ GAL $1 \mathrm{~h}$

$\rightarrow$ GAL $2 h$

Fig 4. Reductive capacity, nicotinamide adenine dinucleotide phosphate (NADPH) system, and metabolic 
permanganometry (HistoNRP) of representative brain tissue sections (A) and 3D surface plots of the same animals (B). (C) NRP-obtained values (greater value indicated increased reductive capacity) represented by individual pixel intensities from 6 different anatomical regions of the brain. (D-M) represent hippocampal samples. Acute oral galactose treatment effect on (D) hippocampal NADPH , (E) total NADP [CTR vs GAL 0.5h $p=.007$; vs GAL 1h $p=.016$; vs GAL 2h p=.007], (F) ratio of reduced to total NADP [CTR vs GAL $0.5 \mathrm{~h} p=.007$; vs GAL 1h $p=.016$; vs GAL 2h p=.007], (G) expression of $\mathrm{c}$-fos [CTR vs GAL 2h p=.082; GAL 0.5h vs GAL $1 \mathrm{~h} p=.052 ;$ ], and (H) galactokinase-1 (GALK-1) normalized to beta-actin [CTR vs GAL 1h p=.038; GAL 0.5h vs GAL 1h $p=.038$ ], and concentration of (I) tissue glutamate [GAL 0.5h vs GAL $2 \mathrm{~h} \mathrm{p=.004;} \mathrm{GAL} 1 \mathrm{~h}$ vs GAL $2 \mathrm{~h} p=.007$ ]. Principal component analysis biplot of the $1^{\text {st }}$ and $2^{\text {nd }}$ principal components with individual animal coordinates based on the group (J) or "overall treatment with GAL" $(K)$. (L) Contribution of individual variables to the $1^{\text {st }}$ and $2^{\text {nd }}$ principal components with a contribution (\%) depicted by color and length of the vector. (M) Comparison of animals by groups based on assigned appropriate coordinates in respect to the $1^{\text {st }}$ and $2^{\text {nd }}$ component respectively [Dim1: CTR vs GAL $0.5 \mathrm{~h} p=.026$; vs GAL $1 \mathrm{~h} p=.002 ;$ vs GAL $2 \mathrm{~h} p=.004$. GAL $0.5 \mathrm{~h}$ vs GAL $1 \mathrm{~h} p=.008$. GAL $1 \mathrm{~h}$ vs GAL $2 \mathrm{~h}$ $\mathrm{p}=.015$. Dim2: CTR vs GAL $2 \mathrm{~h} p=.015$. GAL $1 \mathrm{~h}$ vs GAL $2 \mathrm{~h} p=.026$.]. CTR - control; GAL - galactose; HPC hippocampus; CTX - cortex: SN - substantia nigra; PAG - periaqueductal gray. * [Wilcoxon signed-rank comparisons].

\section{Discussion}

\section{The response of systemic RRN indicators following single oral galactose treatment in rats}

Analysis of the effects of a single dose of galactose administered by oral gavage on plasma and hippocampal RRN revealed several interesting patterns laying the groundworks for further investigation of mechanisms mediating both protective and harmful effects of galactose. Overall, the examination of plasma RRN suggests that acute increment of galactose availability is not sufficient to induce systemic oxidative stress following a single oral administration of $200 \mathrm{mg} / \mathrm{kg}$. Interestingly, malondialdehyde (MDA), a single biomarker of oxidative stress that was significantly altered by the treatment indicates that acute oral galactose decreased rather than increased oxidative stress (Fig 2C). Malondialdehyde is an end-product produced by the degradation of arachidonic acid 
bioRxiv preprint doi: https://doi.org/10.1101/2021.03 08.434370; this version posted March 8, 2021. The copyright holder for this preprint (which was not certified by peer review) is the author/funder, who has granted bioRxiv a license to display the preprint in perpetuity. It is made available under aCC-BY-NC-ND 4.0 International license.

499 and polyunsaturated fatty acids often used as a biomarker of lipid peroxidation, a process of ROS-induced

500 degradation of lipids. The increased concentration of MDA has been reported in various pathological processes

501 such as Alzheimer's disease, Parkinson's disease, diabetes, cardiovascular diseases, cancer, and liver disease ${ }^{58}$.

502 The biological background of this interesting phenomenon remains to be explained, however, our results indicate

503 that oral galactose treatment can either diminish its production possibly by lowering lipid peroxidation, or

504 potentiate the removal of this harmful electrophile aldehyde. One possible mechanism by which galactose could

505 decrease the amount of MDA is by activating an aldehyde scavenger enzyme aldehyde dehydrogenase (ALDH;

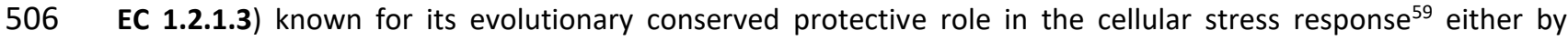

507 hormetic stimulation through the generation of a moderate amount of lipid peroxides, or by replenishment of

508 NADPH pool as further discussed in the text. The organ responsible for the observed effects remains to be

509 determined, however, the liver may mediate some of the changes considering that hepatic tissue shows the

510 highest initial capacity for galactose intake and metabolism ${ }^{9}$. 
bioRxiv preprint doi: https:/doi.org/10.1101/2021.03.08.434370; this version posted March 8, 2021. The copyright holder for this preprint (which was not certified by peer review) is the author/funder, who has granted bioRxiv a license to display the preprint in perpetuity. It is made available under aCC-BY-NC-ND 4.0 International license.

\section{2 Acute reorganization of hippocampal RRN following single oral galactose treatment}

In contrast to systemic effects, RRN analysis of hippocampal tissue revealed a mild pro-oxidative shift with effect

sizes and temporal patterns differing between individual redox subsystems. Paradoxically, a pro-oxidative shift was followed by a subsequent increment of the reductive potential in hippocampal tissue. For example, we observed a decrease of SOD activity after galactose treatment already $0.5 \mathrm{~h}$ after the treatment (Fig $\mathbf{3 A}$ ). A reduction in SOD activity has already been reported after chronic parenteral administration of galactose ${ }^{16,60,61}$, however, to our knowledge this is the first report of acutely decreased activity after oral administration in rats. Apart from SOD, the most pronounced change was observed for the $\mathrm{H}_{2} \mathrm{O}_{2}$ dissociation rate (Fig 3B-C). Chronic parenteral galactose treatment was reported to reduce catalase activity and various anti-aging therapeutics were demonstrated to counteract this change by increasing $\mathrm{H}_{2} \mathrm{O}_{2}$ dissociation capacity ${ }^{18,21,61}$. In contrast, we have found that acute oral treatment increased the $\mathrm{H}_{2} \mathrm{O}_{2}$ dissociation rate (Fig 3B-C). As ROS generation is considered to be the most important molecular mechanism driving galactose-induced senescence, we believe this paradoxical increment of $\mathrm{H}_{2} \mathrm{O}_{2}$ dissociation rate might be induced by substrate-mediated enzyme stimulation and suggests at least some of the changes responsible for the beneficial effects of galactose could be mediated by hormesis - a pathophysiological phenomenon describing a tendency of the biological system to respond to the stressor-induced homeostatic disbalance with protective overcompensation ${ }^{62}$. This is further supported by findings of increased peroxidase-like activity of cytochrome $\mathrm{c}$ (Fig $\mathbf{3 C}$ ) as it has been demonstrated that its peroxidation capacity increases upon protein oxidation by reactive halogen species ${ }^{63}$. Hormetic principles have

531 been extensively studied in the context of oxidative stress where continuous low-level ROS production has been identified as an important regulator of the cellular RRN capacity ${ }^{64,65}$. For example, a mild oxidative stressmediated protective effect has been observed for 3,5,4'-trihydroxy-trans-stilbene also known as resveratrol, a 534 polyphenol with numerous health benefits found in red grapes ${ }^{66}$.

535 A hypothesis that a single oral administration can achieve hormetic levels of galactose in the hippocampus and 536 stimulate redox overcompensation with a consequent increment of RRN capacity is further corroborated by the 537 findings that the total amount of low molecular weight thiols remained practically unchanged by the treatment (Fig 3D), and that protein thiols and lipid peroxidation demonstrated a modest pro-oxidative shift fully 
bioRxiv preprint doi: https:/doi.org/10.1101/2021.03.08.434370; this version posted March 8, 2021. The copyright holder for this preprint (which was not certified by peer review) is the author/funder, who has granted bioRxiv a license to display the preprint in perpetuity. It is made available under aCC-BY-NC-ND 4.0 International license.

redox balance measured by ORP and NRP suggest that galactose treatment resulted in an increased reductive capacity of the hippocampal environment despite a reduction in SOD activity (Fig 3G-I).

Spatiotemporal analysis of tissue reductive capacity by HistoNRP revealed that this hormetic effect was brain region-dependent as this short-term reductive hypercompensation was observed in ventral, but not dorsal hippocampus, and in temporal, but not in parietal cortical regions (Fig 4A-C). In this context, it would be interesting to explore the response of RRN subsystems in brain regions that demonstrated a linear dose-response reduction of antioxidant power following galactose treatment (Fig $\mathbf{4 C}$ ) to see whether the lack of reductive shift was mediated by higher or lower galactose metabolic capacity with corresponding inverse ROS generation potential as this would further strengthen or denounce our hormetic hypothesis. Following the hypothesis that the observed effects were mediated by low levels of oxidative stress and adaptive response mechanisms, we further explored the NADP system as it has been suggested that NADPH-regulated disinhibition of the oxidative pentose phosphate pathway (PPP) flux serves as a rapid ROS detoxification metabolic system conserved across species $^{52,67}$. To combat oxidative stress cells upregulate the transcription of antioxidant defense system components $^{68}$. However, before gene expression yields functional ROS scavengers, the survival of the cell depends on the short-term protective mechanisms that rapidly consume reducing equivalents mostly in the form of $\mathrm{NADPH}^{52,67,69}$. For this mechanism to work efficiently, cells had to evolve rapid and flexible biochemical rerouting strategies to supply substrates into the PPP responsible for the generation of $\mathrm{NADPH}^{52,53,67,69}$. Analysis of hippocampal NADPH supports the hypothesis of galactose-induced mild oxidative stress with hormetic properties as the concentration of NADPH remained unchanged with a slight trend of the increment (Fig 4D). In the context of previously described RRN changes, we believe these findings indicate a potential increase in NADPH turnover with a metabolic rerouting-based replenishment of reducing equivalents used for the restoration of the antioxidant defense systems. This is further supported by the finding that total NADP dramatically increased following oral galactose treatment (Fig 4E) and that the ratio of NADPH and NADP decreased (Fig 4F).

Increased availability and turnover of NADPH observed here is in concordance with a classic cellular adaptive response to ROS since functional metabolic regulation providing substrates for NADP+ reduction not only fuels the most important cellular antioxidant systems such as glutathione peroxidase (GPx; EC 1.11.1.9) but also has the potential to reactivate catalase ${ }^{70}$. Furthermore, a dramatic increment of total NADP following galactose 
bioRxiv preprint doi: https:/doi.org/10.1101/2021.03.08.434370; this version posted March 8, 2021. The copyright holder for this preprint (which was not certified by peer review) is the author/funder, who has granted bioRxiv a license to display the preprint in perpetuity. It is made available under aCC-BY-NC-ND 4.0 International license.

treatment is especially interesting. Oxidative stress has been reported to stimulate rapid phosphorylation of NAD+ to NADP+ by NAD+ kinase (NADK; EC 2.7.1.23) to increase substrate availability for the generation of NADPH. Nevertheless, this mechanism has mostly been described in plants and yeasts ${ }^{71-73}$. In contrast, it has been suggested that human cells generate NADPH to fight oxidative stress not by increasing the NADP+ pool through NADK disinhibition, but through inducible NADP+-dependent dehydrogenase system-mediated replenishment of the reduced dinucleotide fraction ${ }^{73-75}$. This important difference is also reflected in the fact that yeast and plants have three well-defined isoforms of $\mathrm{NADK}^{76}$, while only one gene encoding cytosolic NADK has been identified in mammals in $2001^{77}$, and one additional mitochondrial variant has been described recently with yet undetermined pathophysiological functions ${ }^{78}$. The pathophysiological role of rodent NADK remains largely unexplored. The obvious importance of this enzyme in rodents is reflected in the fact that embryonic lethality arises as a consequence of loss of both NADK alleles in mouse ${ }^{79}$ and that spatiotemporal distribution of NADK activity plays an important role in the development of rat conceptus ${ }^{80}$. Apart from that, some indirect evidence exists that NADK might play an important role in oxidative stress response. Ethanol increases the synthesis of NADP+ in rat hepatocytes most likely as a result of increased NADK ${ }^{81}$ and butyric acid-induced oxidative stress increases NADP+ and the amount of blood cytosolic NADK and decreases NAD+ ${ }^{82}$. Considering the biological relevance of NADP+ and NADK ${ }^{73-75}$, we believe our findings of dramatic increases of hippocampal NADP+ raise some important questions regarding the possible role of NADK on the crossroads of hippocampal RRN and metabolism. Following findings of mild increment of oxidative stress in rat hippocampus after a single oral galactose administration, compensated by metabolic shift with replenishment of NADP-derived reductive equivalents, we wanted to explore whether this metabolic shift would be reflected by a reduction of neuronal metabolic activity marker $\mathrm{c}-\mathrm{fos}^{83,84}$. This was based on the idea that rerouting of metabolic substrates towards the disinhibited oxidative branch of PPP in order to generate NADPH would reduce availability of metabolites for lower glycolysis, and ii) additional protective cellular regulatory mechanisms would be employed to further reduce the availability of $\mathrm{NADH}$ as it might have detrimental pathophysiological effects in the times of weakened reactivity of the cell due to its potential to generate ROS ${ }^{72}$.

Our hypothesis was supported by findings of c-fos expression as acute oral galactose treatment reduced the expression in a time-dependent manner (Fig 4G). We also assumed that, apart from adaptive decrement of cellular activity, increased galactose availability would trigger expression of key enzymatic regulators of the Leloir 
bioRxiv preprint doi: https//doi.org/10.1101/2021.03.08.434370; this version posted March 8, 2021. The copyright holder for this preprint (which was not certified by peer review) is the author/funder, who has granted bioRxiv a license to display the preprint in perpetuity. It is made available under aCC-BY-NC-ND 4.0 International license.

pathway as this would allow the cell to balance energy production and NADPH replenishment in the environmental condition of prolonged galactose availability as G-6-P can be routed both towards lower glycolysis and PPP. As shown in Fig $\mathbf{4 H}$, oral galactose treatment induced expression of GALK-1, an enzyme that catalyzes the first committed step of the Leloir pathway also in a time-dependent manner with increment being the most pronounced at the $2 \mathrm{~h}$ time-point. Lastly, as Reutter's group previously reported that one of the potential mechanisms by which galactose can exert its neuroprotective effects was by consumption of equivalents of ammonia through biosynthesis of amino acids from hexoses, we were interested to see how galactose-induced metabolic dynamics affected hippocampal glutamate homeostasis. The accumulation of glutamate has wellknown neurotoxic effects and its importance has been discussed in the context of Alzheimer's disease ${ }^{85}$. Nevertheless, glutamate also serves as one of the most important excitatory neurotransmitters and plays a major role in the regulation of neuronal energy by its engagement in the glutamate-glutamine cycle, a critical element of the astrocyte-neuron lactate shuttle, one of the prevailing contemporary theoretical frameworks of neuroenergetics ${ }^{86}$. Furthermore, glutamate metabolism is directly coupled to biochemical pathways responsible for the utilization of galactose as the first and rate-limiting enzyme of the hexosamine biosynthesis pathway (HBP), glutamine-fructose-6-phosphate transaminase (GFAT; EC 2.6.1.16) produces glutamate and glucosamine6-phosphate from F-6-P and glutamine. It has been reported that the cellular pool of F-6-P increases in the conditions of increased galactose availability ${ }^{4}$ so it is possible that fueling the protein glycosylation pathways with galactose might also replenish cellular stores of glutamate through the process of transamination. This mechanism might be responsible for the restoration of glutamate stores that are acutely depleted after the treatment (Fig 4I) and corresponds to the increased expression of the Leloir pathway gatekeeper enzyme GALK1 (Fig 4H).

\section{A unique biochemical pattern mediates the protective effects of galactose in the conditions of limited substrate availability}

Current evidence supports the concept that a unique galactose-induced metabolic pattern activates protective mechanisms in the conditions of limited substrate availability ${ }^{4}$. Sasaoka et al. demonstrated that galactose maintains mature protein glycosylation patterns more potently than glucose or mannose ${ }^{4}$. Considering the importance of protein glycosylation this finding indicates that galactose might preserve energy-sensitive cellular 
bioRxiv preprint doi: https:/doi.org/10.1101/2021.03.08.434370; this version posted March 8, 2021. The copyright holder for this preprint (which was not certified by peer review) is the author/funder, who has granted bioRxiv a license to display the preprint in perpetuity. It is made available under aCC-BY-NC-ND 4.0 International license.

functions in times of reduced substrate availability. Maintenance of protein glycosylation patterns is especially important for growth factor signaling as both growth factors and their receptors are known to be heavily glycosylated and sensitive to perturbations of energy availability ${ }^{87}$. Interestingly, even the presence of trace amounts of galactose $(0.3 \mathrm{mM})$ in the conditions of reduced substrate availability was able to correct starvationinduced disruption of insulin-like growth factor I (IGF-I) and epidermal growth factor (EGF) maturation and signaling in the HEK293 cells while the effect was not observed in the presence of the same amount of glucose $\mathrm{e}^{4}$. The ability of galactose to maintain the function of growth factor signaling might even be directly related to its ability to stimulate rapid phosphorylation of NAD+ (Fig 4E) as it was recently reported that growth factors such as insulin or IGF-I exert direct control over NADK through Akt-mediated phosphorylation ${ }^{88}$. Furthermore, oxidative stress is a well-known consequence of reduced nutrient availability. Increased concentrations of superoxide radicals and $\mathrm{H}_{2} \mathrm{O}_{2}$ have been reported after starvation of glucose, glutamine, pyruvate, serum or amino acids, and starvation-induced generation of ROS has even been suggested as the main regulator of autophagy ${ }^{89,90}$. In this context, the fact that galactose favors PPP over glycolysis makes it even more interesting for the preservation of cellular function during starvation, as besides growth factor signaling maintenance galactose provides substrates indispensable for the replenishment of cellular antioxidant defense reserves that are rapidly consumed by starvation-induced ROS. Diverting metabolism towards PPP might also activate other adaptive mechanisms for example by the rescue of glyceraldehyde-3-phosphate dehydrogenase (GAPDH; EC 1.2.1.12) through decreasing availability of its substrate glyceraldehyde-3-phosphate (G-3-P) as liberated GAPDH acts as a transcriptional regulator ${ }^{56,57}$.

In summary, a large body of evidence supports the hypothesis that galactose has been selected by evolution as an ideal sugar to help the cells overcome fluctuations in the availability of energy substrates and maintain growth factors-related signaling. This hypothesis makes even more sense in the context of the fact that the importance of galactose seems to be the most pronounced in the brain, the most vulnerable and energy-dependent organ, and in the suckling period, the most vulnerable and energy-dependent period of life in mammals. In this context, it is possible that the same biochemical strategy that enables galactose to protect the brain from energy scarcity during the developmental period can be exploited to provide an alternative source of energy, replenish cellular stores of antioxidants, maintain protein glycosylation patterns, and rescue growth factor signaling during the process of neurodegeneration also characterized as a vulnerable period of reduced availability of energy 
bioRxiv preprint doi: https:/doi.org/10.1101/2021.03.08.434370; this version posted March 8, 2021. The copyright holder for this preprint (which was not certified by peer review) is the author/funder, who has granted bioRxiv a license to display the preprint in perpetuity. It is made available under aCC-BY-NC-ND 4.0 International license.

652

653

654

655

656

657

658

659

660

661

662

663

664

665

666

667

668

669

670

671

672

673

674

675

676

677

678

679

680

substrates. This concept is supported by findings from our group as long-term oral galactose treatment both

prevents $^{8}$ and ameliorates ${ }^{38}$ cognitive deficits in the rat model of sporadic Alzheimer's disease induced by intracerebroventricular administration of streptozotocin (STZ-icv) characterized by disrupted insulin signaling in the brain ${ }^{91}$. Furthermore, oral galactose has been shown to normalize brain glucose metabolism both in STZ-icv ${ }^{38}$ and in the Tg2576 model of Alzheimer's disease ${ }^{42}$.

\section{Galactose might exert its effects through hormesis: A hypothetical explanation of the relationship between protective effects of galactose and galactose-induced ROS}

To conclude, ample evidence supports the hypothesis that galactose serves a unique biochemical role offering protection in times of limited substrate availability. However, evidence that continuous administration of galactose induces oxidative stress cannot be ignored, especially given the fact that a large number of groups exploit this effect to model aging in animals ${ }^{92}$. Based on the aforementioned, the inevitable question arises. How could it be that galactose induces oxidative stress, but also protects the cell from fluctuations in energy availability and increases the capacity of cells to tolerate ROS? We believe the findings reported here and the context provided by results reported by other groups provide a possible explanation for this perplexing paradox.

It could be that a specific metabolic reorganization following galactose administration is a direct consequence of the ability of galactose to induce tolerable amounts of cellular oxidative stress. In other words, it is possible that activation of specific biochemical machinery in the presence of galactose, which is responsible for the protective effects against oxidative stress and fluctuations of nutrient availability, is in fact hormetic in its nature. This hypothesis is supported by findings from other groups as metabolic dynamics following galactose treatment resemble biochemical reorganization following acute oxidative stress challenges. Disinhibition of the substrate flux into the oxidative branch of PPP with consequent replenishment of NADPH is considered to be an evolutionary conserved mechanism of protection against ROS present in different species ${ }^{52}$ and the presence of galactose seems to favor the same substrate utilization pattern ${ }^{56,57}$. Furthermore, oxidative stress-induced inhibition of glycolysis is further reinforced through the inactivation of gatekeeper enzymes, GAPDH and PFK-193. In mammalian cells GAPDH serves as a pleiotropic sensor of oxidative stress through several mechanisms, the most important being direct ROS-induced intramolecular disulfide formation at active site cysteines and enzyme S-thiolation considered to be an important protective mechanism enabling the cell to rapidly resume glycolysis 
bioRxiv preprint doi: https//doi.org/10.1101/2021.03.08.434370; this version posted March 8, 2021. The copyright holder for this preprint (which was not certified by peer review) is the author/funder, who has granted bioRxiv a license to display the preprint in perpetuity. It is made available under aCC-BY-NC-ND 4.0 International license.

681

682

683

684

685

686

687

688

689

690

691

692

693

694

695

696

697

698

699

700

701

702

703

704

705

706

and ATP production after the oxidative stress subsides ${ }^{93}$. PFK-1, a critical glycolytic enzyme that serves a ratelimiting function and that is directly responsible for the first committed step of glycolysis is also inhibited following ROS challenge possibly through TP-53-induced glycolysis and apoptosis regulator (TIGAR) $)^{93,94}$. Interestingly, the metabolic activity of GAPDH is decreased in the presence of galactose ${ }^{56,57}$, and recent observations suggest that, unlike glucose that increases the activity of the glycolytic gatekeeper enzyme PFK-1, the presence of galactose affects neither concentration nor activity of the enzyme ${ }^{4}$ enabling substrate shuttling towards the PPP. Furthermore, an increased expression of TIGAR has been reported in N2a cells when cultured in the presence of galactose ${ }^{95}$. Considering the aforementioned evidence, it is possible that the similarity of metabolic dynamics induced by galactose and ROS is not coincidental, and that the biochemical fate of galactose depends on its ability to activate the ROS-sensitive regulatory machinery of the cell. In this context, alternative galactose metabolic pathways, mainly catalyzed by aldose reductase (AR; EC 1.1.1.21) and galactose dehydrogenase (EC 1.1.1.48) are especially interesting as they are considered an important source of galactoseinduced ROS. This is supported by findings reported by Li et al. who investigated the effect of galactose in malignant and non-malignant cell lines following the hypothesis that interruption of glycolysis might be an attractive approach to cancer therapy ${ }^{95}$. Interestingly, the effect of galactose in malignant cells was annihilated following pretreatment with sorbinil, a specific inhibitor of $A R^{95}$, indicating that accessory metabolic pathways might play an important role in specific galactose-induced orchestration of biochemical machinery responsible for the observed effects. It also cannot be ruled out that galactose-induced hormesis might also be dependent on oxidative metabolism that generates a substantial amount of ROS as it has been shown that cells cultured in galactose media heavily rely on oxidative phosphorylation machinery, and this principle has been exploited for screening of fibroblasts from patients in whom respiratory chain-related defects have been suspected ${ }^{96}$ and for studying oxidative metabolism in human primary muscle cells ${ }^{97}$. In this context, galactose-induced protective effects might be related to mitohormesis ${ }^{98}$. Further research more closely focused on supra acute effects of galactose, monitoring lactate-to-pyruvate ratios, and exploiting pharmacological and genetic manipulation with mitochondrial energetics might provide important information on whether and how mitohormesis might contribute to the overall observed hormetic effect. 
bioRxiv preprint doi: https:/doi.org/10.1101/2021.03 08.434370. this version posted March 8,2021 . The copyright holder for this preprint (which was not certified by peer review) is the author/funder, who has granted bioRxiv a license to display the preprint in perpetuity. It is made available under aCC-BY-NC-ND 4.0 International license.

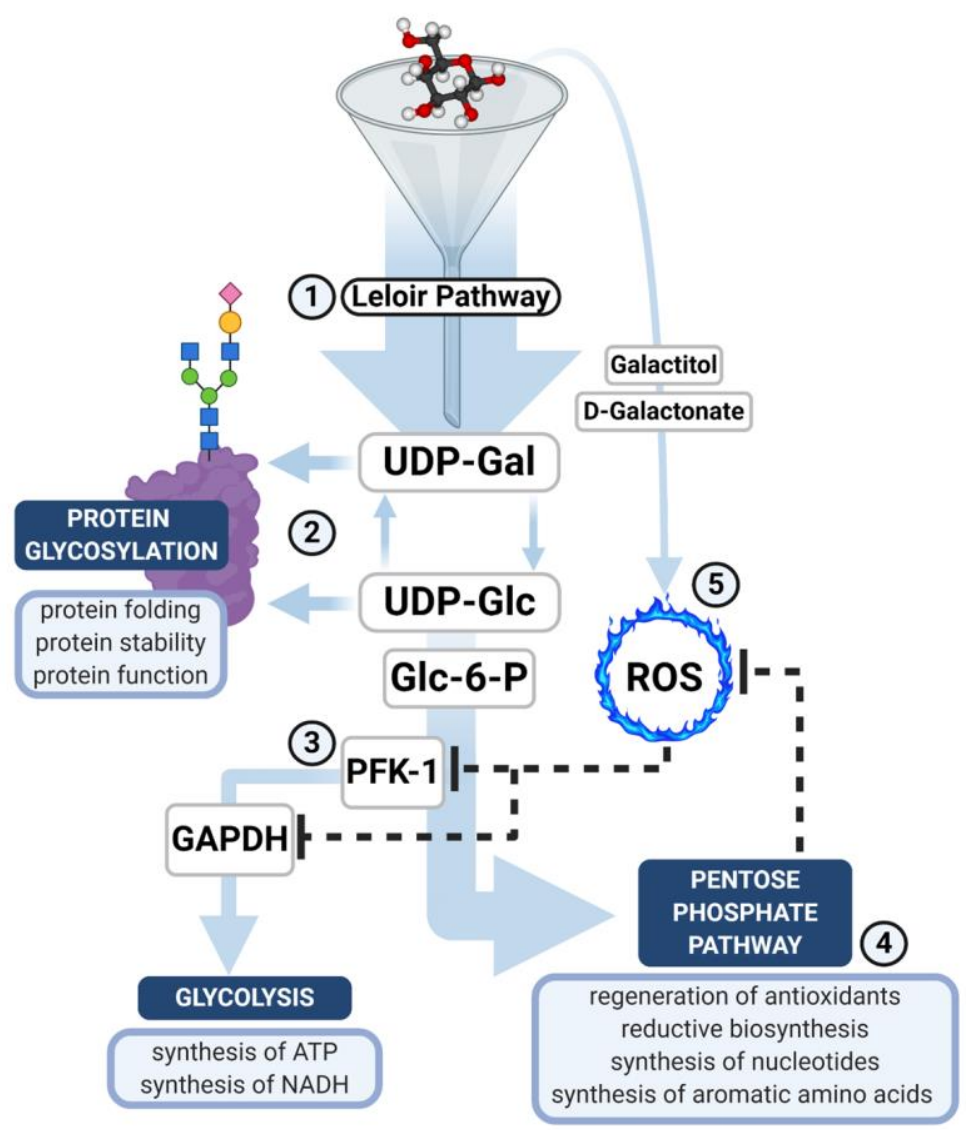

Fig 5. Schematic representation of potential biochemical pathways involved in galactose-induced hormesis.

Leloir pathway (1) is considered as the most important metabolic route of galactose contributing biochemical regeneration of cellular antioxidants and reductive biosynthesis. Alternative metabolic pathways (e.g. metabolism to galactitol or D-galactonate) might act as regulators of the cellular galactose shuttle by stimulating the generation of ROS (5) that could then decide the fate of galactose in the cell by inhibiting critical regulatory enzymes such as PFK-1 and GAPDH, and hence rerouting galactose-generated G-6-P towards the PPP with the net effect being i) preserved glycosylation; ii) reduced metabolic activity and iii) regeneration of antioxidants, synthesis of nucleotides, and reductive biosynthesis. 


\section{Further considerations and implications of the hormetic hypothesis of galactose in humans} and animals unique monosaccharide. Better insights into how galactose orchestrates cellular metabolic response would help us understand the pathophysiological background in animal models of parenteral galactose-induced aging, in case of inherited disorders of metabolism, and even its physiological importance. Regarding animal models, understanding the fine line between hormesis-mediated activation of protective cellular mechanisms, and detrimental consequences of the saturation of metabolic pathways would provide context important for understanding the perplexing results of animal experiments concerning galactose administration. Both the route of administration and the dose-response to galactose are critical components of galactose research that remain poorly understood. Because current evidence speaks in favor of galactose metabolic capacity of the cell as a critical factor for the determination of pathophysiological consequences of increased galactose availability, and that both factors exert significant influence over local galactose availability in different tissues, a proper understanding of these concepts is indispensable for interpretation of the results of animal studies on galactose. A plethora of studies have shown the detrimental effects of parenteral galactose ${ }^{18,92}$, while oral galactose administration seems to exert beneficial effects at least in different animal models of Alzheimer's disease $\mathrm{e}^{8,38,42}$. Different explanations have been proposed considering these findings. For example, it has been shown that unlike intraperitoneal administration, oral galactose treatment increases the secretion of neuroprotective incretin glucagon-like peptide-1 (GLP-1 $)^{38}$ and it has been speculated that it might provide neuroprotective effects through modulation of gut microbiota and stimulation of afferent fibers of the vagus nerve ${ }^{99}$. Another possible explanation of these findings is a much larger and rapid increment of galactose availability following the intraperitoneal administration. For example, plasma galactose concentration is two times higher following intraperitoneal administration in comparison to orogastric gavage (208\% vs $111 \%$ increment) in STZ-icv rats 15 
bioRxiv preprint doi: https:/doi.org/10.1101/2021.03.08.434370; this version posted March 8,2021 . The copyright holder for this preprint (which was not certified by peer review) is the author/funder, who has granted bioRxiv a license to display the preprint in perpetuity. It is made available under aCC-BY-NC-ND 4.0 International license.

Based on the analysis of the effects of acute oral galactose treatment on plasma and hippocampal redox

compared to the untreated group even in the group sacrificed 30 minutes following treatment indicating most of the galactose is absorbed and/or metabolized in this time window (Fig 2G).

The importance of local dynamics of galactose availability is further corroborated by the findings that the beneficial effects of galactose on cognitive performance have also been reported following subcutaneous administration ${ }^{39}$. Furthermore, oral administration of galactose can also have detrimental effects in certain circumstances although the physiological gastrointestinal barrier acts to buffer the rapid entrance of large amounts of galactose into the body. In particular, it seems that long-term oral treatment has the potential to induce harmful changes when galactose is repeatedly given in bolus doses through orogastric gavage even at relatively low doses ${ }^{40,100}$. From the hormetic hypothesis standpoint, local differences in cellular galactose availability that arise as a consequence of different experimental designs (often through pharmacokinetics) might explain the discrepant findings reported in the literature. For example, in our experiments, galactose achieved the best neuroprotective effect when it was dissolved in drinking water and administered throughout the day ${ }^{8,38}$. Interestingly, plasma concentrations of galactose were either unchanged or even decreased in these animals in comparison to controls that didn't drink galactose indicating that galactose metabolic capacity was not exceeded in these animals ${ }^{38}$. Another important caveat is to consider possible differences arising as a consequence of disturbed metabolism, rendering particular strains and animal models more susceptible or resistant to the observed hormetic effect. Although our preliminary results suggest neuroprotective properties of galactose are not unique for the STZ-icv model, and that they are also present in healthy animals [unpublished results], at the present moment most of the evidence is based on the findings from the rat model of sporadic Alzheimer's disease with yet uncharacterized galactose metabolism. Furthermore, the concept of hormesis is intrinsically dependent on cellular compensatory capacity, and it is rational to anticipate some pathophysiological states will alter the efficacy of this approach by diminishing the ability of the cell to either withstand the original noxis or respond appropriately once the stimulus subsides.

\section{Conclusion} regulatory networks we propose that acute oral galactose treatment does not induce perturbations of the 
bioRxiv preprint doi: https:/doi.org/10.1101/2021.03.08.434370; this version posted March 8,2021 . The copyright holder for this preprint (which was not certified by peer review) is the author/funder, who has granted bioRxiv a license to display the preprint in perpetuity. It is made available under aCC-BY-NC-ND 4.0 International license. systemic redox networks in the dose of $200 \mathrm{mg} / \mathrm{kg}$ while the same dose is sufficient to induce a subtle prooxidative shift in the hippocampus that is (over)compensated in the first 2 hours following administration. The exact mechanism responsible for the observed (over)compensation remains to be further explored, however, rapid disinhibition of the oxidative PPP flux, a gradual reduction in neuronal activity, and increment of the expression of Leloir pathway gatekeeper enzyme GALK1 suggest a metabolic reorganization favoring the evolutionary conserved ROS detoxification metabolic system. Based on the observed changes, and in the context of findings reported by other groups, we propose a hormetic hypothesis of galactose action indicating that, at the biochemical level, protective effects of galactose might be inseparable from its ability to induce tolerable levels of cellular ROS.

\section{Limitations of our study}

Being exploratory in its design, it is rational to conclude that our study did not achieve optimal power to detect potential alterations in all of the examined redox subsystems due to inherent limitations of particular biochemical methods or due to other reasons. For this reason, we clearly emphasize this throughout the text, and we discuss the observed changes without the "fixation on p-values". Due to a relatively small number of animals and relatively large standard deviation, the trends we observed could just as well be meaningful and significant biological changes, and some significant differences could just as well be simple artifacts. We don't consider this to be critical in this type of exploratory study where we were more focused on the association between particular subsystems and the effect on the redox regulatory network as a whole. Particular changes we observed remain in our focus and will be more clearly examined with the appropriate experimental design in our future experiments. Another critical limitation is the fact that we base our idea of the biochemical time-response on data obtained from individual animals randomized to different groups. In this regard, biochemical analysis of biological samples with repeated measurements of particular parameters would have been much more suitable for the assessment of acute galactose time response. Nevertheless, at this moment, it is impossible to conduct this kind of experiment. One option was a continuous sampling of extracellular fluid with the microdialysis probe placed in the particular hippocampal region, however, our experiments showed that i) placement of the probe, 
bioRxiv preprint doi: https:/doi.org/10.1101/2021.03.08.434370; this version posted March 8,2021 . The copyright holder for this preprint (which was not certified by peer review) is the author/funder, who has granted bioRxiv a license to display the preprint in perpetuity. It is made available under aCC-BY-NC-ND 4.0 International license.

\section{Conflict of Interest:}

\section{Author's contributions:}

Nothing to disclose.

ii) pain associated with it, iii) flushing the tissue with artificial extracellular fluid, or iv) simply a biased recovery of particular molecules could affect the estimate of activity of the biological mechanisms we were interested in exploring in the dialysate (Supplementary material). The results obtained this way would therefore probably provide a poor representation of the biochemical changes that occur in reality. Another important limitation that should be emphasized is that no differentiation of neuronal and glial aspects was included in our study, and the results are only informative for the hippocampus in general. Differentiation of the hormetic effect on neuronal and glial cells remains the focus of our future experiments. Finally, we wish to draw the attention of the readers to one theoretical limitation related to the fact that for this purpose the term ROS was used throughout the text in a relatively general way to describe a large amount of pro-oxidative molecules involved in a similar and interrelated biochemical relationship with redox homeostatic systems. For some parameters we discuss, other terms would be more suitable (e.g. RCS - reactive carbonyl species) ${ }^{101}$.

$\mathbf{J H}, \mathbf{A B P}, \mathbf{A K}$, and JOB conducted the in vivo part of the experiment. $\mathbf{J H}$ established and validated biochemical methods for RRN analysis, and conducted measurements of SOD, LMWT, protein sulfhydryl content, TBARS, ORP, NRP, $\mathrm{H}_{2} \mathrm{O}_{2}$ dissociation rate, cytochrome c peroxidase-like activity, and HistoNRP. JH, ABP and AK, conducted measurements of NADP and NADPH, and Western blots for c-fos and GALK-1. ABP, AK, and JOB measured glutamate ELISA, glucose, and galactose. JH conducted data curation, analysis, and visualization, and wrote the manuscript. ABP, AK, JOB, IK, DV, PR, and MSP discussed the results, commented on the manuscript, and provided critical feedback. MSP (mentor of JH and PI of the lab) supervised the project and provided funding. 


\section{Funding source:}

830

831 This work was funded by the Croatian Science Foundation (IP-2018-01-8938). The research was co-financed by

832 the Scientific Centre of Excellence for Basic, Clinical, and Translational Neuroscience (project "Experimental and

833 clinical research of hypoxic-ischemic damage in perinatal and adult brain"; GA KK01.1.1.01.0007 funded by the

834 European Union through the European Regional Development Fund).

\section{Ethics committee approval:}

838 All experiments were conducted in concordance with the highest standard of animal welfare. Only certified

839 personnel handled animals. Animal procedures were carried out at the University of Zagreb Medical School

840 (Zagreb, Croatia) and complied with current institutional, national (The Animal Protection Act, NN135/2006; NN

841 47/2011), and international (Directive 2010/63/EU) guidelines governing the use of experimental animals. The

842 experiments were approved by the national regulatory body responsible for issuing ethical approvals, the 
845

846

847

848

849

850

851

852

853

854

855

856

857

858

859

860

861

862

863

864

865

866

867

868

869

870

871

872

873

874

875

876

877

878

879

880

881

882

\section{References}

1. Pasteur, L. Note sur le sucre de lait. Comptes rendus l'Académie des Sci 42, 347-351 (1856).

2. Coelho, A. I., Berry, G. T. \& Rubio-Gozalbo, M. E. Galactose metabolism and health. Curr Opin Clin Nutr Metab Care 18, 422-427 (2015).

3. Urashima, T., Messer, M. \& Oftedal, O. T. Comparative Biochemistry and Evolution of Milk Oligosaccharides of Monotremes, Marsupials, and Eutherians. in Evolutionary Biology: Genome Evolution, Speciation, Coevolution and Origin of Life (ed. Pontarotti, P.) 3-33 (Springer International Publishing, 2014). doi:10.1007/978-3-319-07623-2_1.

4. Sasaoka, N., Imamura, H. \& Kakizuka, A. A Trace Amount of Galactose, a Major Component of Milk Sugar, Allows Maturation of Glycoproteins during Sugar Starvation. iScience 10, 211-221 (2018).

5. Schwartz, N. B. \& Domowicz, M. S. Proteoglycans in brain development and pathogenesis. FEBS Lett 592, 3791-3805 (2018).

6. K.Yu, R. \& Schengrund, C.-L. Glycobiology of the Nervous System. vol. 9 (Springer International Publishing, 2014).

7. Sosicka, P., Ng, B. G. \& Freeze, H. H. Therapeutic Monosaccharides: Looking Back, Moving Forward. Biochemistry 59, 3064-3077 (2020).

8. Salkovic-Petrisic, M. et al. Long-term oral galactose treatment prevents cognitive deficits in male Wistar rats treated intracerebroventricularly with streptozotocin. Neuropharmacology 77, 6880 (2014).

9. Roser, M. et al. Metabolism of galactose in the brain and liver of rats and its conversion into glutamate and other amino acids. J Neural Transm 116, 131 (2008).

10. Finkel, T. \& Holbrook, N. J. Oxidants, oxidative stress and the biology of ageing. Nature 408, 239-247 (2000).

11. Lai, K., Elsas, L. \& Wierenga, K. Galactose Toxicity in Animals. IUBMB Life 61, 1063-1074 (2009).

12. OMIM Entry - \# 230200 - GALACTOSEMIA II; GALAC2.

13. OMIM Entry - \# 230400 - GALACTOSEMIA I; GALAC1.

14. Lai, K., Langley, S. D., Khwaja, F. W., Schmitt, E. W. \& Elsas, L. J. GALT deficiency causes UDPhexose deficit in human galactosemic cells. Glycobiology 13, 285-294 (2003).

15. Knerr, l. et al. Effects of temporary low-dose galactose supplements in children aged 5-12 y with classical galactosemia: a pilot study. Pediatric Research 78, 272-279 (2015).

16. Ho, S.-C., Liu, J.-H. \& Wu, R.-Y. Establishment of the mimetic aging effect in mice caused by Dgalactose. Biogerontology 4, 15-18 (2003).

17. Azman, K. F. \& Zakaria, R. D-Galactose-induced accelerated aging model: an overview. Biogerontology 20, 763-782 (2019).

18. Shwe, T., Pratchayasakul, W., Chattipakorn, N. \& Chattipakorn, S. C. Role of D-galactoseinduced brain aging and its potential used for therapeutic interventions. Experimental Gerontology 101, 13-36 (2018). 
19. Kubo, E., Urakami, T., Fatma, N., Akagi, Y. \& Singh, D. P. Polyol pathway-dependent osmotic and oxidative stresses in aldose reductase-mediated apoptosis in human lens epithelial cells: role of AOP2. Biochem Biophys Res Commun 314, 1050-1056 (2004).

20. Dvornik, E. et al. Polyol accumulation in galactosemic and diabetic rats: control by an aldose reductase inhibitor. Science 182, 1146-1148 (1973).

21. Cui, X. et al. D-galactose-caused life shortening in Drosophila melanogaster and Musca domestica is associated with oxidative stress. Biogerontology 5, 317-325 (2004).

22. Wu, D. et al. Purple sweet potato color repairs d-galactose-induced spatial learning and memory impairment by regulating the expression of synaptic proteins. Neurobiol Learn Mem 90, 1927 (2008).

23. Liu, H. et al. Astaxanthin attenuates D-galactose-induced brain aging in rats by ameliorating oxidative stress, mitochondrial dysfunction, and regulating metabolic markers. Food Funct. 11, 41034113 (2020).

24. Oyebode, O. T., Giwa, O. D. \& Olorunsogo, O. O. Comparative effects of galactose-induced aging on mitochondrial permeability transition in rat liver and testis. Toxicol Mech Methods 30, 388396 (2020).

25. Mirshafa, A. et al. Tropisetron protects against brain aging via attenuating oxidative stress, apoptosis and inflammation: The role of SIRT1 signaling. Life Sciences 248, 117452 (2020).

26. Guo, B. et al. D-Galactose-induced oxidative stress and mitochondrial dysfunction in the cochlear basilar membrane: an in vitro aging model. Biogerontology 21, 311-323 (2020).

27. Tavanai, E., Mohammadkhani, G., Farahani, S. \& Jalaie, S. Protective Effects of Silymarin Against Age-Related Hearing Loss in an Aging Rat Model. Indian J Otolaryngol Head Neck Surg 71, 1248-1257 (2019).

28. Hadzi-Petrushev, N., Stojkovski, V., Mitrov, D. \& Mladenov, M. D-galactose induced changes in enzymatic antioxidant status in rats of different ages. Physiol Res 64, 61-70 (2015).

29. Xiao, P., Huang, H., Li, X., Chen, J. \& Duan, J.-A. Characterization, evaluation of nutritional parameters of Radix isatidis protein and its antioxidant activity in D-galactose induced ageing mice. BMC Complement Altern Med 19, 297 (2019).

30. Liu, X. et al. Partially Hydrolyzed Guar Gum Attenuates d-Galactose-Induced Oxidative Stress and Restores Gut Microbiota in Rats. Int J Mol Sci 20, (2019).

31. Chen, P., Chen, F. \& Zhou, B. Leonurine ameliorates D-galactose-induced aging in mice through activation of the Nrf2 signalling pathway. Aging (Albany NY) 11, 7339-7356 (2019).

32. Khan, M. et al. 17ß-Estradiol Modulates SIRT1 and Halts Oxidative Stress-Mediated Cognitive Impairment in a Male Aging Mouse Model. Cells 8, (2019).

33. He, S. et al. Potential effects of rapeseed peptide Maillard reaction products on aging-related disorder attenuation and gut microbiota modulation in d-galactose induced aging mice. Food Funct 10, 4291-4303 (2019).

34. Liu, C.-M., Ma, J.-Q. \& Lou, Y. Chronic administration of troxerutin protects mouse kidney against D-galactose-induced oxidative DNA damage. Food Chem Toxicol 48, 2809-2817 (2010).

35. Homolak, J. et al. Separating science from science fiction: A non-existent enzyme is a primary driver of pathophysiological processes in galactose-induced rodent models of aging. $R G$ preprint (2020) doi:10.13140/RG.2.2.31233.89449/1. 
36. Lu, J. et al. Ursolic acid attenuates D-galactose-induced inflammatory response in mouse prefrontal cortex through inhibiting AGEs/RAGE/NF-KB pathway activation. Cereb Cortex 20, 25402548 (2010).

37. Rehman, S. U., Shah, S. A., Ali, T., Chung, J. I. \& Kim, M. O. Anthocyanins Reversed DGalactose-Induced Oxidative Stress and Neuroinflammation Mediated Cognitive Impairment in Adult Rats. Mol Neurobiol 54, 255-271 (2017).

38. Knezovic, A. et al. Glucagon-like peptide-1 mediates effects of oral galactose in streptozotocin-induced rat model of sporadic Alzheimer's disease. Neuropharmacology 135, 48-62 (2018).

39. Chogtu, B. et al. Evaluation of Acute and Chronic Effects of D-Galactose on Memory and Learning in Wistar Rats. Clin Psychopharmacol Neurosci 16, 153-160 (2018).

40. Budni, J. et al. Oral administration of d-galactose induces cognitive impairments and oxidative damage in rats. Behav Brain Res 302, 35-43 (2016).

41. Oliveira, M. F., Geihs, M. A., França, T. F. A., Moreira, D. C. \& Hermes-Lima, M. Is "Preparation for Oxidative Stress" a Case of Physiological Conditioning Hormesis? Front. Physiol. 9, (2018).

42. Babic Perhoc, A. et al. Cognitive, behavioral and metabolic effects of oral galactose treatment in the transgenic Tg2576 mice. Neuropharmacology 148, 50-67 (2019).

43. Lowry, O. H., Rosebrough, N. J., Farr, A. L. \& Randall, R. J. Protein measurement with the Folin phenol reagent. J Biol Chem 193, 265-275 (1951).

44. Collin, F. Chemical Basis of Reactive Oxygen Species Reactivity and Involvement in Neurodegenerative Diseases. International Journal of Molecular Sciences 20, 2407 (2019).

45. Cao, T., He, M., Bai, T. \& Liu, H. Establishment of a Method for Measuring Antioxidant Capacity in Urine, Based on Oxidation Reduction Potential and Redox Couple 12/KI. Bioinorg Chem Appl 2016, 7054049 (2016).

46. Hadwan, M. H. Simple spectrophotometric assay for measuring catalase activity in biological tissues. BMC Biochem 19, (2018).

47. Li, X. Improved Pyrogallol Autoxidation Method: A Reliable and Cheap Superoxide-Scavenging Assay Suitable for All Antioxidants. J. Agric. Food Chem. 60, 6418-6424 (2012).

48. Prabhakar, P. V. et al. Oxidative stress induced by aluminum oxide nanomaterials after acute oral treatment in Wistar rats. J Appl Toxicol 32, 436-445 (2012).

49. Van der Plancken, I., Van Loey, A. \& Hendrickx, M. E. G. Changes in Sulfhydryl Content of Egg White Proteins Due to Heat and Pressure Treatment. J. Agric. Food Chem. 53, 5726-5733 (2005).

50. Feissner, R., Xiang, Y. \& Kranz, R. G. Chemiluminescent-based methods to detect subpicomole levels of c-type cytochromes. Anal Biochem 315, 90-94 (2003).

51. Homolak, J. et al. Nitrocellulose redox permanganometry: a simple method for reductive capacity assessment | bioRxiv. (2020).

52. Christodoulou, D. et al. Reserve Flux Capacity in the Pentose Phosphate Pathway by NADPH Binding Is Conserved across Kingdoms. iScience 19, 1133-1144 (2019).

53. Kuehne, A. et al. Acute Activation of Oxidative Pentose Phosphate Pathway as First-Line Response to Oxidative Stress in Human Skin Cells. Mol Cell 59, 359-371 (2015). 
54. Grant, C. M. Metabolic reconfiguration is a regulated response to oxidative stress. J Biol 7, 1 (2008).

55. Ralser, M. et al. Dynamic rerouting of the carbohydrate flux is key to counteracting oxidative stress. J Biol 6, 10 (2007).

56. Green, D. R. \& Rathmell, J. Sweet Nothings: Sensing of Sugar Metabolites Controls T Cell Function. Cell Metabolism 18, 7-8 (2013).

57. Chang, C.-H. et al. Posttranscriptional control of T cell effector function by aerobic glycolysis. Cell 153, 1239-1251 (2013).

58. Ayala, A., Muñoz, M. F. \& Argüelles, S. Lipid peroxidation: production, metabolism, and signaling mechanisms of malondialdehyde and 4-hydroxy-2-nonenal. Oxid Med Cell Longev 2014, 360438 (2014).

59. Singh, S. et al. Aldehyde dehydrogenases in cellular responses to oxidative/electrophilic stress. Free Radic Biol Med 56, 89-101 (2013).

60. Fatemi, I. et al. Protective effect of metformin on D-galactose-induced aging model in mice. Iran J Basic Med Sci 21, 19-25 (2018).

61. Kumar, A., Dogra, S. \& Prakash, A. Effect of carvedilol on behavioral, mitochondrial dysfunction, and oxidative damage against D-galactose induced senescence in mice. Naunyn Schmiedebergs Arch Pharmacol 380, 431-441 (2009).

62. Calabrese, E. J. Hormesis: improving predictions in the low-dose zone. Exp Supp/ 101, 551564 (2012).

63. Chen, Y.-R., Deterding, L. J., Sturgeon, B. E., Tomer, K. B. \& Mason, R. P. Protein oxidation of cytochrome $C$ by reactive halogen species enhances its peroxidase activity. J Biol Chem 277, 2978129791 (2002).

64. Costantini, D. Oxidative Stress and Hormesis in Evolutionary Ecology and Physiology: A Marriage Between Mechanistic and Evolutionary Approaches. (Springer-Verlag, 2014). doi:10.1007/978-3-642-54663-1.

65. Poljsak, B., Šuput, D. \& Milisav, I. Achieving the balance between ROS and antioxidants: when to use the synthetic antioxidants. Oxid Med Cell Longev 2013, 956792 (2013).

66. Plauth, A. et al. Hormetic shifting of redox environment by pro-oxidative resveratrol protects cells against stress. Free Radic Biol Med 99, 608-622 (2016).

67. Christodoulou, D. et al. Reserve Flux Capacity in the Pentose Phosphate Pathway Enables Escherichia coli's Rapid Response to Oxidative Stress. Cell Syst 6, 569-578.e7 (2018).

68. Martindale, J. L. \& Holbrook, N. J. Cellular response to oxidative stress: signaling for suicide and survival. J Cell Physiol 192, 1-15 (2002).

69. Stincone, A. et al. The return of metabolism: biochemistry and physiology of the pentose phosphate pathway. Biol Rev Camb Philos Soc 90, 927-963 (2015).

70. Scott, M. D., Zuo, L., Lubin, B. H. \& Chiu, D. T. NADPH, not glutathione, status modulates oxidant sensitivity in normal and glucose-6-phosphate dehydrogenase-deficient erythrocytes. Blood 77, 2059-2064 (1991).

71. Brumaghim, J. L., Li, Y., Henle, E. \& Linn, S. Effects of hydrogen peroxide upon nicotinamide nucleotide metabolism in Escherichia coli: changes in enzyme levels and nicotinamide nucleotide pools and studies of the oxidation of NAD(P)H by Fe(III). J Biol Chem 278, 42495-42504 (2003). 
72. Grose, J. H., Joss, L., Velick, S. F. \& Roth, J. R. Evidence that feedback inhibition of NAD kinase controls responses to oxidative stress. Proc Natl Acad Sci U S A 103, 7601-7606 (2006).

73. Ying, W. NAD+/NADH and NADP+/NADPH in cellular functions and cell death: regulation and biological consequences. Antioxid Redox Signal 10, 179-206 (2008).

74. Kawai, S. \& Murata, K. Structure and function of NAD kinase and NADP phosphatase: key enzymes that regulate the intracellular balance of NAD(H) and NADP $(H)$. Biosci Biotechnol Biochem 72, 919-930 (2008).

75. Pollak, N., Niere, M. \& Ziegler, M. NAD kinase levels control the NADPH concentration in human cells. J Biol Chem 282, 33562-33571 (2007).

76. Pollak, N., Dölle, C. \& Ziegler, M. The power to reduce: pyridine nucleotides - small molecules with a multitude of functions. Biochem J 402, 205-218 (2007).

77. Lerner, F., Niere, M., Ludwig, A. \& Ziegler, M. Structural and functional characterization of human NAD kinase. Biochem Biophys Res Commun 288, 69-74 (2001).

78. Zhang, R. MNADK, a Long-Awaited Human Mitochondrion-Localized NAD Kinase. J Cell Physiol 230, 1697-1701 (2015).

79. Shianna, K. V., Marchuk, D. A. \& Strand, M. K. Genomic characterization of POS5, the Saccharomyces cerevisiae mitochondrial NADH kinase. Mitochondrion 6, 94-101 (2006).

80. Akella, S. S. \& Harris, C. Developmental Ontogeny of NAD+ Kinase in the Rat Conceptus. Toxicology and Applied Pharmacology 170, 124-129 (2001).

81. Akinshola, B. E., Potter, J. J. \& Mezey, E. Ethanol increases the formation of NADP+ in rat hepatocytes. Hepatology 13, 509-514 (1991).

82. Cueno, M. E., Imai, K., Tamura, M. \& Ochiai, K. Butyric acid-induced rat jugular blood cytosolic oxidative stress is associated with SIRT1 decrease. Cell Stress Chaperones 19, 295-298 (2014).

83. Dragunow, M. \& Faull, R. The use of c-fos as a metabolic marker in neuronal pathway tracing. J Neurosci Methods 29, 261-265 (1989).

84. Herrera, D. G. \& Robertson, H. A. Activation of c-fos in the brain. Prog Neurobio/ 50, 83-107 (1996).

85. Lewerenz, J. \& Maher, P. Chronic Glutamate Toxicity in Neurodegenerative Diseases-What is the Evidence? Front Neurosci 9, (2015).

86. Mason, S. Lactate Shuttles in Neuroenergetics-Homeostasis, Allostasis and Beyond. Front Neurosci 11, (2017).

87. Takahashi, M., Tsuda, T., Ikeda, Y., Honke, K. \& Taniguchi, N. Role of N-glycans in growth factor signaling. Glycoconj J 20, 207-212 (2003).

88. Hoxhaj, G. et al. Direct stimulation of NADP+ synthesis through Akt-mediated phosphorylation of NAD kinase. Science 363, 1088-1092 (2019).

89. Filomeni, G., Desideri, E., Cardaci, S., Rotilio, G. \& Ciriolo, M. R. Under the ROS...thiol network is the principal suspect for autophagy commitment. Autophagy 6, 999-1005 (2010).

90. Chen, Y., Azad, M. B. \& Gibson, S. B. Superoxide is the major reactive oxygen species regulating autophagy. Cell Death Differ 16, 1040-1052 (2009). 
91. Grünblatt, E., Salkovic-Petrisic, M., Osmanovic, J., Riederer, P. \& Hoyer, S. Brain insulin system dysfunction in streptozotocin intracerebroventricularly treated rats generates hyperphosphorylated tau protein. J Neurochem 101, 757-770 (2007).

92. Sadigh-Eteghad, S. et al. D-galactose-induced brain ageing model: A systematic review and meta-analysis on cognitive outcomes and oxidative stress indices. PLoS One 12, e0184122 (2017).

93. Mullarky, E. \& Cantley, L. C. Diverting Glycolysis to Combat Oxidative Stress. in Innovative Medicine: Basic Research and Development (eds. Nakao, K., Minato, N. \& Uemoto, S.) (Springer, 2015).

94. Jenkins, C. M., Yang, J., Sims, H. F. \& Gross, R. W. Reversible high affinity inhibition of phosphofructokinase-1 by acyl-CoA: a mechanism integrating glycolytic flux with lipid metabolism. $J$ Biol Chem 286, 11937-11950 (2011).

95. Li, N. et al. D-galactose induces necroptotic cell death in neuroblastoma cell lines. J Cell Biochem 112, 3834-3844 (2011).

96. Robinson, B. H., Petrova-Benedict, R., Buncic, J. R. \& Wallace, D. C. Nonviability of cells with oxidative defects in galactose medium: a screening test for affected patient fibroblasts. Biochem Med Metab Biol 48, 122-126 (1992).

97. Aguer, C. et al. Galactose enhances oxidative metabolism and reveals mitochondrial dysfunction in human primary muscle cells. PLoS One 6, e28536 (2011).

98. Bárcena, C., Mayoral, P. \& Quirós, P. M. Mitohormesis, an Antiaging Paradigm. Int Rev Cell Mol Biol 340, 35-77 (2018).

99. Salkovic-Petrisic, M. Oral Galactose Provides a Different Approach to Incretin-Based Therapy of Alzheimer's Disease. Journal of Neurology \& Neuromedicine 3, (2018).

100. Krzysztoforska, K. et al. Administration of protocatechuic acid affects memory and restores hippocampal and cortical serotonin turnover in rat model of oral D-galactose-induced memory impairment. Behav Brain Res 368, 111896 (2019).

101. Semchyshyn, H. M. Reactive Carbonyl Species In Vivo: Generation and Dual Biological Effects. The Scientific World Journal https://www.hindawi.com/journals/tswj/2014/417842/ (2014) doi:https://doi.org/10.1155/2014/417842. 